\title{
ABATEMENT OF WETLAND LOSS IN LOUISLANA THROUGH DIVERSIONS OF MISSISSIPPI RIVER WATER USING SIPHONS
}

\author{
by \\ David W. Roberts ${ }^{1}$, Johannes L. van Beek ${ }^{1}$, and Stephen Fournet ${ }^{1}$ \\ S. Jeffress Williams ${ }^{2}$ \\ USGS Science Officer and Editor
}

\section{Open-File Report 92-274}

This report was prepared under contract to the U.S. Geological Survey and has not been reviewed for conformity with USGS editorial standards or with the North American Stratigraphic Code. Opinions and conclusions expressed herein do not necessarily represent those of the USGS. Any use of trade, product, or firm names is for descriptive purposes only and does not imply endorsement by the U.S. Government.

\footnotetext{
${ }^{1}$ Coastal Environments, Inc., Baton Rouge, LA

2 U.S. Geological Survey, 914 National Center, Reston, VA 22092
} 


\begin{abstract}
Maintaining the wetlands of the Mississippi River Deltaic Plain requires the introduction of both river sediments and river water into the estuaries. River sediments rebuild lost wetlands and help offset the accretion deficit in remaining wetlands; river water controls salinities. However, to date, only diversions to provide freshwater for salinity control have been implemented. This study evaluates to what extent these freshwater diversions can contribute to wetland maintenance through associated sediments. The potential sediment contribution from freshwater diversions was determined by examining the discharge and sediment load characteristics of the Mississippi River and the constraints posed on the operation of diversion structures by fisheries resources. It was discovered that within these constraints, freshwater diversion could be maximized for wetland maintenance purposes from December through March, and a 24 percent increase in sediment introduction achieved. Additionally, a field study was undertaken of the diversion of suspended sediment from the Mississippi River through a siphon and the fate of these sediments in the outfall area. During the study period, the siphon added 70.3 milhon $\mathrm{m}^{3}(57,000 \mathrm{ac}-\mathrm{ft})$ of freshwater and 12 milhon $\mathrm{kg}$ (13,200 tons) of sediment to the Breton Sound estuary. However, it was discovered that only a small portion of this sediment contributes to wetland maintenance because of deposition in the outfall canal, bypassing of the wetlands, and limited transport beyond the channel banks. Freshwater diversions constitute a major source of sediments for wetland maintenance when considering the quantity of sediments introduced, but effective use of this resource requires careful selection of diversion locations, management of the outfall, and timing of diversion discharges relative to river conditions and estuarine water levels.
\end{abstract}




\section{TABLE OF CONTENTS}

Abstract $\ldots \ldots \ldots \ldots \ldots \ldots \ldots \ldots \ldots \ldots \ldots \ldots \ldots \ldots \ldots \ldots \ldots \ldots$

List of Figures $\ldots \ldots \ldots \ldots \ldots \ldots \ldots \ldots \ldots \ldots \ldots \ldots \ldots \ldots$

List of Tables $\ldots \ldots \ldots \ldots \ldots \ldots \ldots \ldots \ldots \ldots \ldots \ldots \ldots \ldots \ldots \ldots$ iv

Conversion Factors $\ldots \ldots \ldots \ldots \ldots \ldots \ldots \ldots \ldots \ldots \ldots \ldots \ldots$

Acknowledgements $\ldots \ldots \ldots \ldots \ldots \ldots \ldots \ldots \ldots \ldots \ldots \ldots \ldots$

Chapter 1 Introduction $\ldots \ldots \ldots \ldots \ldots \ldots \ldots \ldots \ldots \ldots \ldots \ldots \ldots \ldots$

Diversion of Mississippi River Water and Sediment ........ 1

Chapter 2 Goals and Contrainsts of Freshwater Diversions $\ldots \ldots \ldots \ldots$

The Role of Freshwater Diversion ................ 5

Goals of Freshwater Diversion ................. 6

Sediment Availability for Wetland Maintenance ........... 8

Operation for Wetland Maintenance ............... 15

Chapter 3 Field Study of the White's Ditch Siphon . . . . . . . . . . . . 17

Description of the Study Area . . . . . . . . . . . . . 17

Methods and Materials ..................... 17

River Stages and Tidal Conditions ............. 19

Water and Sediment Discharge . . . . . . . . . . . 20

Bottom Sediment Fractions . . . . . . . . . . . . . . . . 20

Areal Extent of Freshwater and Sediment

Dispersion into Wetlands ................ 20

Effects of Diversion On Wetland Accretion ........... 21

Results and Discussion .................... 23

River Stages and Tidal Conditions .............. 23

Water and Sediment Discharge . . . . . . . . . . . . 24

Bottom Sediment Fractions .................... 30

Extent of Diversion Into Wetlands . . . . . . . . . . . . . . . 32

Effects of Diversion on Wetland Accretion ............ 32

Implications for Wetland Conservation and Management . . . . 41

Chapter 4 Summary and Conclusions $\ldots \ldots \ldots \ldots \ldots \ldots \ldots \ldots \ldots$

Freshwater Diversion .................... 43

Field Study - White's Ditch . . . . . . . . . . . . . . . . 44

References ............................ 47

Appendices $\ldots \ldots \ldots \ldots \ldots \ldots \ldots \ldots \ldots \ldots \ldots \ldots \ldots \ldots \ldots \ldots$ 


\section{LIST OF FIGURES}

1-1. Locations of freshwater diversion projects alongthe lower

Mississippi River in Louisiana ...................... 3

1-2. Setting of the White's Ditch Siphon $\ldots \ldots \ldots \ldots \ldots \ldots \ldots \ldots \ldots$

2-1. Relationship of estuarine hydrology to zonation of wetland habitats $\ldots \ldots \ldots \ldots \ldots \ldots \ldots \ldots \ldots \ldots \ldots$

2-2. An index of temporal movement of commercially important

estuarine fisheries species in relatio to freshwater

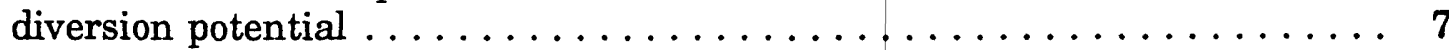

2-3. Mean monthly salinity, range, and standard error for good oyster years from stations on the public seed grounds in Breton Sound and modified target salinities for operation of the Caernarvon freshwater diversion structure $\ldots \ldots \ldots \ldots \ldots \ldots .9$

2-4. The relationships of Mississippi River discharge to total suspended sediment (TSS) and the sand and silt-clay fractions at Tarbert Landing, 1972-1989

2-5. Relationships between Mississippi River discharge and the silt and clay fractions of the suspended sediment concentration for Tarbert Landing, 1972-1989

2-6. Monthly mean and standard error for discharge and total suspended sediment at Tarbert Landing, 1972-1989

2-7. Monthly mean and standard error for sand, silt, and clay concentrations at Tarbert Landing, 1972-1989 and predicted sand concentration at Belle Chasse . . . . . . . . . . . . . . 14

2-8. Critical temperatures and stages in the Mississippi River and Breton Sound in Comparison with goal salinities of the Caernarvon freshwater diversion project $\ldots \ldots \ldots \ldots \ldots \ldots \ldots$

3-1. Regional setting of the study area $\ldots \ldots \ldots \ldots \ldots \ldots \ldots \ldots \ldots \ldots$

3-2. Field sampling stations in the White's Ditch study area $\ldots \ldots \ldots \ldots 19$

3-3. Views of the ceramic sediment traps in place before the marsh burn at ME (above) and on retrieval (below) ............. 22

3-4. Mississippi River stages at the siphon intake and tidal stages at the siphon outfall from January through August $1990 \ldots \ldots \ldots 23$

3-5. Continuous water-level records in the Belair Canal, periods of siphon operation, and sampling events $\ldots \ldots \ldots \ldots \ldots \ldots$

3-6. Channel cross-section profiles at discharge measurement sites $\ldots \ldots \ldots 26$ 
3-7. Discharge (cfs) and change in total suspended sediment (TSS)

distribution downstream during the four sampling events $\ldots \ldots \ldots \ldots 28$

3-8. Flow diagrams showing the distribution of water and sediment at the discharge measurement sites $\ldots \ldots \ldots \ldots \ldots \ldots \ldots \ldots \ldots 29$

3-9. Grain-size components of bottom sediment cores from surface samples $(5 \mathrm{~cm})$ and composite samples $(62 \mathrm{~cm})$ in the Belair Canal

3-10. The distribution of water temperatures and salinity in water bodies during the marsh survey $\ldots \ldots \ldots \ldots \ldots \ldots \ldots 33$

3-11. Distribution of suspended sediment concentrations in marsh water during the survey $\ldots \ldots \ldots \ldots \ldots \ldots \ldots \ldots \ldots$

3-12. Distribution of the mineral content (percent dry weight) in marsh soils sampled during the marsh survey $\ldots \ldots \ldots \ldots \ldots \ldots$

3-13. The water, organic, and mineral volume of marsh soil at marsh experimental (ME) and control (MC) sites . . . . . . . . . 37

3-14. Sediment accretion as a function of distance from the stream bank at the marsh experimental and control

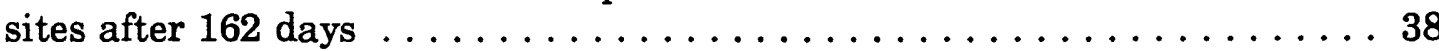

3-15. Results of the sediment trapping study at the marsh experimental (ME) and control (MC) sites

\section{LIST OF TABLES}

3-1. Estimation of the C Factor in the Standard Weir Equation from Emperical Data on the White's Ditch Siphon ............ 30

3-2. Physical Characteristics of Marsh Soils from Experimental and Control Sites as a Function of Distance from the

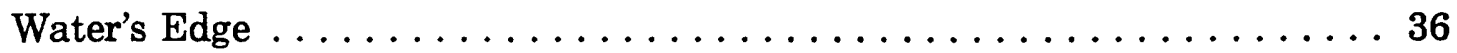

3-3. Variability of the Marsh Surface at Marsh Study Sites $\ldots \ldots \ldots \ldots . \ldots 39$ 


\section{CONVERSION FACTORS}

For use of readers who prefer to use metric units, conversion factors for terms used in this report are listed below:

\begin{tabular}{lc|l}
\hline \multicolumn{1}{c|}{ Multiply } & By & \multicolumn{1}{c}{ To Obtain } \\
acre & 0.405 & \multicolumn{1}{c}{ hectare (ha) } \\
acre-foot & 1,234 & cubic meter \\
cubic foot per second (cfs) & 0.02832 & cubic meter per second \\
(cms) & & \\
foot (ft) & 0.3048 & meter (m) \\
foot per second (ft/s) & 0.3048 & meter per second (m/s) \\
gallon (gal) & 3.785 & liter (L) \\
inch (in) & 25.40 & millimeter (mm) \\
& 2.540 & centimeter (cm) \\
mile (mi) & 1.609 & kilometer $(\mathrm{km})$ \\
pound (lb) & 0.4536 & kilogram (kg) \\
& 453.6 & gram (g) \\
tons & 907.20 & kilogram (kg) \\
\hline
\end{tabular}

To convert temperature in degree Celsius $\left({ }^{\circ} \mathrm{C}\right)$ to degree Fahrenheit $\left({ }^{\circ} \mathrm{F}\right)$, multiply by $9 / 5$ and add 32 . 


\section{ACKNOWLEDGEMENTS}

Contributions were made to this study and report by a number of people. Foremost has been the contribution of Mr. S. Jeffress Williams, the U.S. Geological Survey Science Officer for this project. His sincere interest and constructive criticism, together with an unprecedented patience, provided a very much appreciated part of the work environment. Dr. Joann Mossa of the Louisiana Geological Survey shared with us her knowledge of the Mississippi River sediment load. Staff of the U.S. Army Corps of Engineers, New Orleans District, provided assistance with the acquisition of discharge data. The siphon study was facilitated by operational information provided by Mr. Pete Jones of the Plaquemines Parish Health Department and access provided to the siphon outfall area by Judge Robert Lobrano. Steven Fournet, Gary Cox, and Mark Miller all aided with various phases of the field data collection and sample analysis. Linda Abadie edited the report. Technical reviews by Michael Ierardi and Dr. Rick Stumpf of the U.S. Geological Survey are appreciated. 


\section{CHAPTER 1 INTRODUCTION}

The long-term maintenance and renewal of the wetland resource base of the Mississippi River Deltaic Plain cannot be accomplished without diversion of sediment-laden water from the Mississippi and Atchafalaya Rivers. However, such diversions are subject to severe constraints that relate to present water and land resource uses and funding. These constraints apply particularly to diversions that emphasize sediment rather than freshwater because of the greater discharge and structural needs and resultant perturbation of the receiving area. It is because of these constraints that the implementation of major diversions is a slow process, that diversions have focused on freshwater rather than sediments, and that operation of freshwater diversions for fish and wildlife purposes could limit their wetland maintenance contribution. The present study addresses these aspects by examining: (1) the extent to which freshwater diversions can contribute to wetland maintenance through sediment introduction, and (2) the effectiveness of small diversions through siphons as an interim or supplemental wetland maintenance measure.

\section{Diversion of Mississippi River Water and Sediment}

Projects to divert Mississippi River water into adjacent estuarine basins can be placed into two categories: sediment diversions and freshwater diversions. The purpose of sediment diversion projects is to restore and maintain wetlands. To restore wetlands lost as a result of relative subsidence and erosion requires the building of new subdeltas into shallow water bodies. Diversion of flow from the Mississippi River for this purpose must transport large quantities of both coarse and fine-grained sediments out of the river and therefore require channelized flow similar to a natural distributary. Diversion structures are envisioned as lined, open channels that connect directly to the main river channel, perhaps containing a low sill to control channel enlargement. Such diversions are most feasible and effective in the upper estuaries when considering gradients and subsidence rates but are less controversial in the lower estuaries where wetlands have been replaced by shallow bays and where adverse effects on existing resource uses are more limited. No such diversions have been planned at present.

Maintenance of existing wetlands also requires the introduction of water and sediment from the Mississippi River, but diversion requirements are different and generally of a lesser magnitude than those for wetland restoration. The greatest need for diversion stems from the existence of an accretion deficit as a result of relative subsidence of the marsh substrate. Clastic sediments are needed to augment accumulation of organic materials, but the sediment requirement is limited to the finer fractions that can be distributed through transport in suspension by water overflowing the wetland at low velocities. Diverted water may thus be obtained from the upper part of the Mississippi River water column and diversion can be accomplished through gated culverts or pipes. These sediment diversions are most effective in the upper estuary.

An additional diversion need is caused by adverse hydrologic conditions, including saltwater intrusion, that relate to wetland loss and man-made changes of the estuary. Diversions directed at salinity control for purposes of wetland protection and management of aquatic habitats for fish and wildlife resources should be considered freshwater 
diversions, as opposed to sediment diversions. Because freshwater benefits also depend in part on the extent to which water is dispersed through the wetlands, sediment diversions for wetland maintenance are likely to provide freshwater benefits as well. However, a sediment diversion, in most cases, will exceed the discharge requirements for salinity control because the structure would be operated at full capacity at all times. In contrast, freshwater diversions will be operated within specific tolerances that relate to habitat requirements, life cycles of commercially important species, and precipitation and evapotranspiration. These tolerances may limit sediment diversion to less than the full potential.

Design and operation of the diversions presently implemented or proposed along the lower Mississippi River emphasize freshwater introduction to manage wetland and aquatic habitats for fish and wildlife resources, and as a wetland maintenance measure to protect freshwater and low-salinity wetland plants from salt-related stress. This means that for the immediate future, sediment introduction for the maintenance of wetlands in the upper estuaries of the Mississippi River Deltaic Plain will be dependent on the extent to which these freshwater diversions can accommodate sediment diversion needs or can be augmented by additional diversions.

To date, two medium-size diversions have been implemented along the east bank of the Mississippi River below New Orleans (Figure 1-1). Both are freshwater diversions to control water salinities for oyster production in the Breton Sound estuary. Of these two diversions, the Caernarvon structure, with a discharge capacity of 243 cubic meters per second (cms) [8600 cubic foot per second (cfs)], is located in the upper estuary and is likely to provide the greatest sediment benefits if outfall from the structure is adequately managed. The structure was completed at the end of 1990 , but has not been operated to date because of low water salinities. The second, the Bayou Lamoque structure, is located further downstream and discharges into open water of the Breton Sound where suspended sediments contribute to wetland maintenance only to the extent they are subsequently transported into the marshes by tidal water movement. Two additional structures have been planned and designed for future implementation, pending Federal-state cooperation and funding. These are the Davis Pond, $297 \mathrm{cms}(10,500 \mathrm{cfs})$, and Bonnet Carre, $708 \mathrm{cms}(25,000 \mathrm{cfs})$, structures that will divert Mississippi River water into the Barataria Basin and Lake Pontchartrain estuaries, respectively.

Even after implementation of these diversions, there remains a wetland maintenance deficit because of a number of reasons. They include the mentioned emphasis on freshwater rather than sediment diversion, limited magnitude of the total capacity, and location of the diversion structures relative to the estuarine environment. Even at full capacity, the planned diversion structures together will divert only 6 percent of the average annual flood flow of the Mississippi River below the Old River Control Structure. This amount is considerably less than the historic discharge through overbank flow, crevasses, and distributaries. In addition, the Bonnet Carre structure will have limited wetland maintenance benefits because of diversion into the open water of Lake Pontchartrain. Sedimentation benefits of the Davis Pond structure will be much greater, even though they are somewhat constrained by discharge routing through Lakes Cataouatche and Salvador and by limited water distribution to the eastern margin of the Barataria estuary because of geomorphic and hydrologic constraints.

Because of the current shortfall in sediment suppletion, and in some areas freshwater as well, and the difficulty in implementing large-scale diversions in a short 


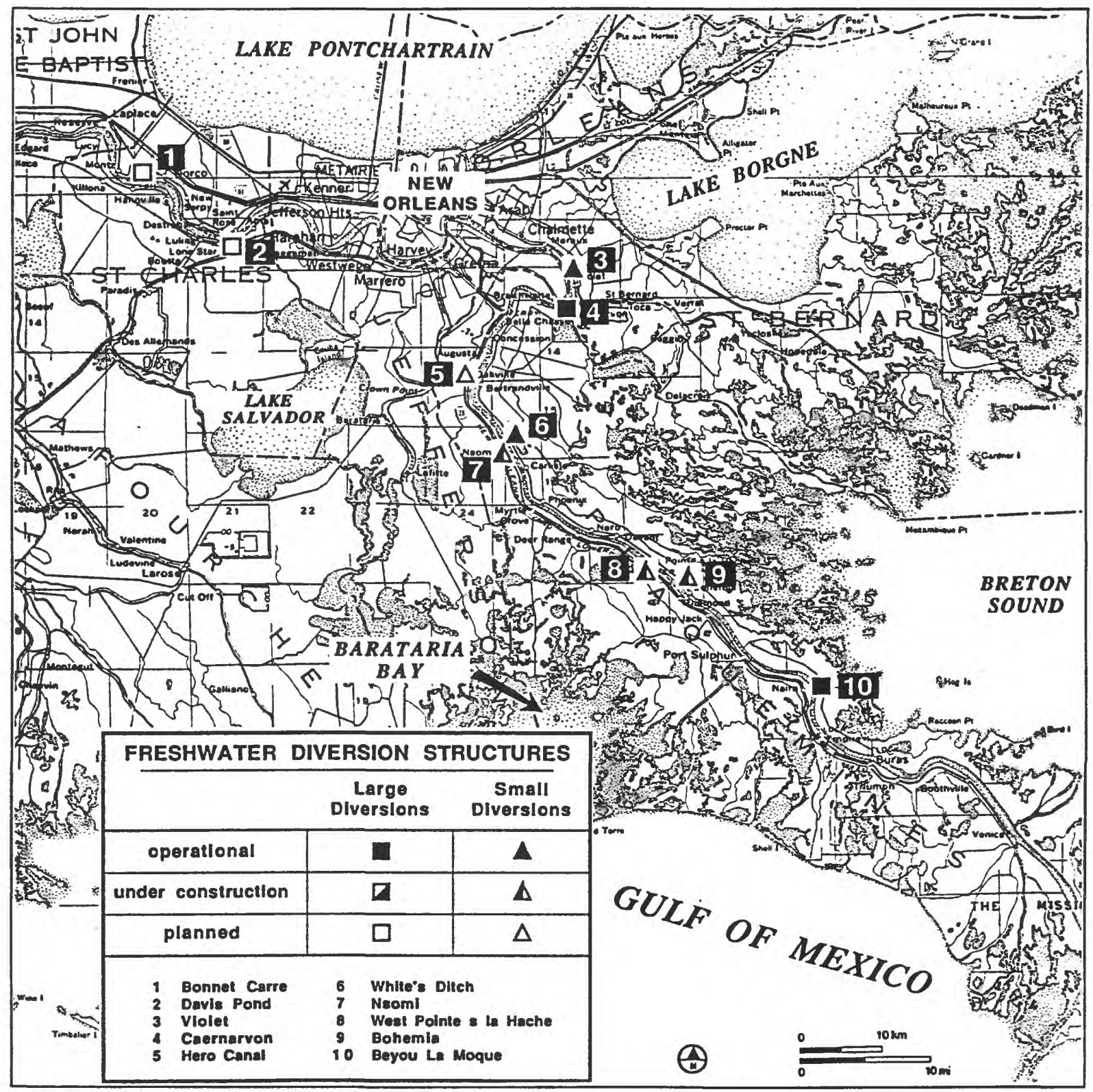

Figure 1-1. Locations of freshwater diversion projects along the lower Mississippi River in Louisiana (operational, under construction, and planned.)

time-frame, efforts have begun to supplement these larger diversions by smaller structures directed at specific areas. Consideration must furthermore be given to optimize sediment utilization from the existing and planned freshwater diversions. Without short-term enhancement through some freshwater and sediment introduction, wetlands will be predictably lost before major additional freshwater and sediment diversion structures can be implemented. Such losses not only reduce the total area of remaining wetlands, they also limit benefits from future diversions because of reduced potential for sediment retention in the outfall areas.

In many areas along the Mississippi River development corridor, opportunities exist for small-scale diversions and the achievement of substantial benefits from such 
diversions. Specifically, these are the diversions of Mississippi River water and sediment by means of siphons. Precedents for this type of diversion presently exist. A $7.1 \mathrm{cms}$ (250-cfs) siphon diversion (Figure 1-2) has been in operation at White's Ditch in Plaquemines Parish since 1975. In 1979 , a siphon diversion of $14.2 \mathrm{cms}$ (500 cfs) was implemented at Violet in St. Bernard Parish. While it is recognized that water and sediment delivery from a single siphon is limited when considering the overall estuarine need, benefits are believed to be significant because of time gained for implementation of larger diversions. The much smaller cost and limited constraints with regard to right-of-way, breaching of main-line flood control levees, and implementation makes siphon projects feasible for local and/or state government. Two siphons, Naomi and West Pointe a la Hache (Figure 1-1), are being implemented under a cooperative agreement between state and local government along the west bank of the Mississippi River in Plaquemines Parish.

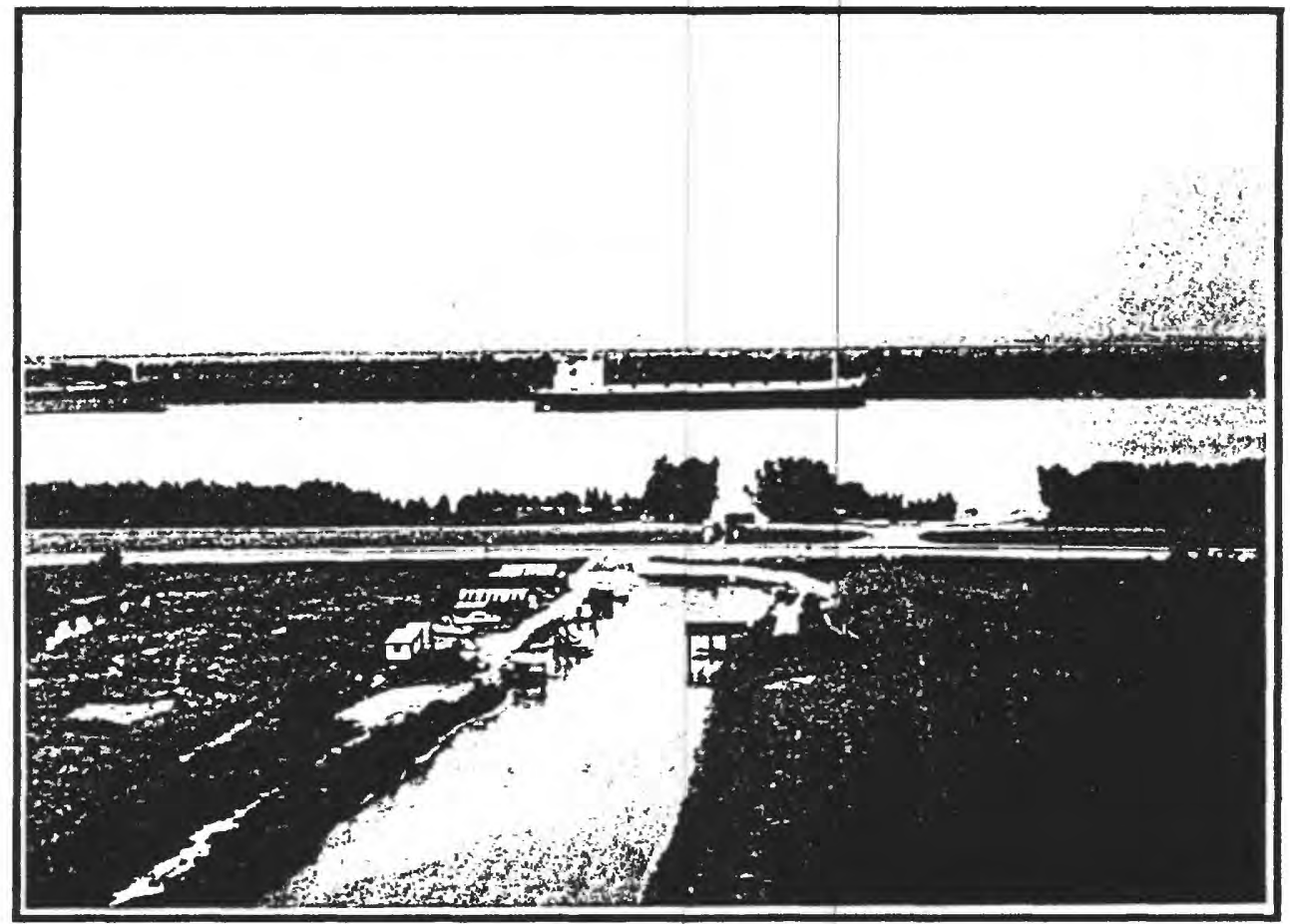

Figure 1-2. Setting of the White's Ditch Siphon. The two pipes in the center of the photograph connect the Mississippi River with the siphon outfall canal. 


\section{CHAPTER 2 \\ GOALS AND CONSTRAINTS OF FRESHWATER DIVERSIONS}

\section{The Role of Freshwater Diversion}

The primary goal of current freshwater diversions is to manage the productivity of wildlife and fishery resources by controlling salinity, with a secondary benefit to marsh maintenance. Actual operation of a diversion structure requires more specific objectives because of differences in preferred salinities and temperatures among the various species of plants and animals during certain times of the year and the needs to maintain specific habitat types in certain areas. These objectives place constraints on the operation of large-scale diversion structures from a sediment-suppletion point-of-view.

Freshwater diversions are preferably situated at the upper end of the estuarine basin, because input at the landward end is consistent with the natural hydrological and ecological patterns. The suppletion of freshwater at the upper end of the basin helps maintain a seaward hydraulic gradient during the greater portion of the year, thereby sustaining the habitat gradient from fresh to saline wetlands. Minimal daily tidal fluctuations in the upper basin and natural retention of water by the wetlands allow precipitation and runoff to accumulate, forming a freshwater head (Figure 2-1). This provides for the occurrence of swamp and fresh marsh as the predominant wetland habitats. At the seaward end of the basin, tidal water movement results in the introduction of saline water and mixing with the basin's freshwater to produce estuarine conditions and brackish-to-saline wetland habitats (Figure 2-1). Attenuation of tidal energy in a landward direction, due to the friction provided by emergent wetlands, creates a pattern of decreasing salinities. In the region where the freshwater head and the tidal envelope equalize, an ecotone of intermediate marsh is found. This pattern will be maintained as long as freshwater input and retention of the freshwater in the upper basin are sufficient to maintain the freshwater head. The requirement for freshwater increases, however, as subsidence and the associated land loss continue to remove the frictional barriers to tidal propagation, allowing tidal water exchange and salinities to increase. Freshwater diversion to the upper basin helps to counter this process and to restore the natural balance.

By introducing freshwater at the upper end of the basin, the natural tendency to maintain a freshwater head through frictional retention is utilized. Likewise introduction of water at the upper end of the estuary maximizes the potential for incorporation of the suspended sediments into the wetland substrate and uptake of the dissolved nutrients by emergent plants. These subsidies help offset the aggradational deficit in the wetlands imposed by subsidence. Also, by maximizing contact of diverted water and the wetlands, chemical contaminants are filtered out and incorporated in the substrate, and biological contaminants, such as coliform bacteria, are reduced before coming into contact with the fisheries habitats in the lower basin. 


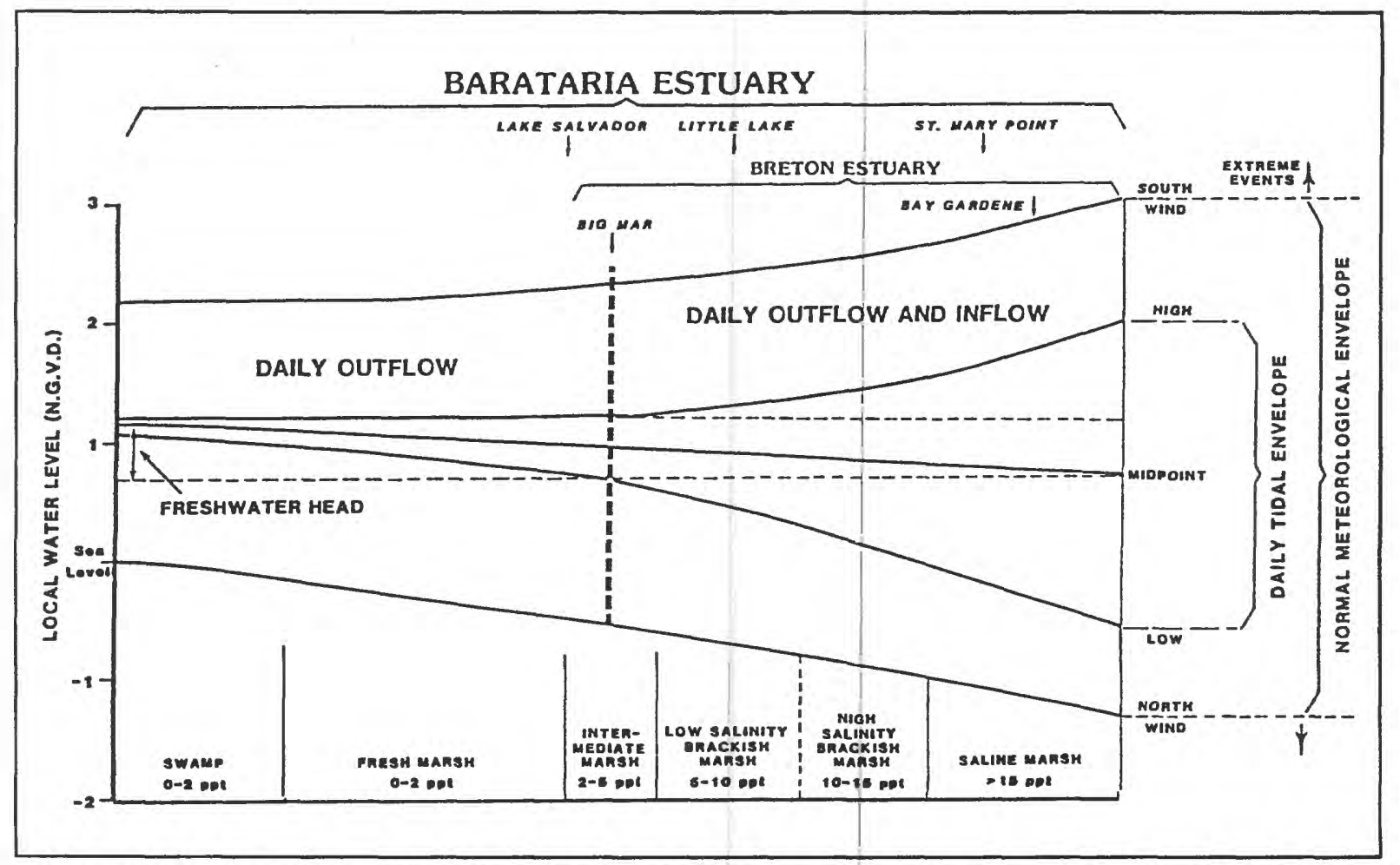

Figure 2-1. Relationship of estuarine hydrology to zonation of wetland habitats.

\section{Goals of Freshwater Diversion}

Optimum habitats for wildlife and fisheries resources generally reside on opposite ends of the estuarine basin. Wildlife is generally more abundant in the fresher habitats (swamp, fresh marsh, intermediate marsh). Since it is freshwater input that is being controlled, operation for management of wildlife resources is unconstrained other than by water levels. Maximum output of the control structure would be the operating criteria for salinity control. On the other hand, the fisheries resources depend upon the immigration and emigration of larval, post-larval, and juvenile organisms in the saline, brackish, and intermediate marsh nursery grounds. Survival and growth of these small organisms is greatly influenced by water parameters such as salinity and temperature. In addition, these organisms inhabit the nursery grounds in waves of peak abundance throughout the year, with different species coming in different seasons. This is illustrated for some of the more commercially important species in Figure 2-2. The estuarine-dependent species will utilize different marsh nursery areas as dictated by their salinity and temperature preferences at the season of their arrival. Therefore, it is not possible to control freshwater input to maximize overall fisheries production; it must be targeted at certain species. This situation becomes more evident when the availability of freshwater is considered. Figure 2-2 shows that the brown shrimp (Penaeus aztecus) is the only one of the commercially important species shown that can be directly influenced by freshwater diversion. The literature indicates that the colder water temperatures that are likely to result from input of river water will reduce brown shrimp production (Lindall and others, 1972; Barrett and Gillespie, 1973; Smith, 1979). 

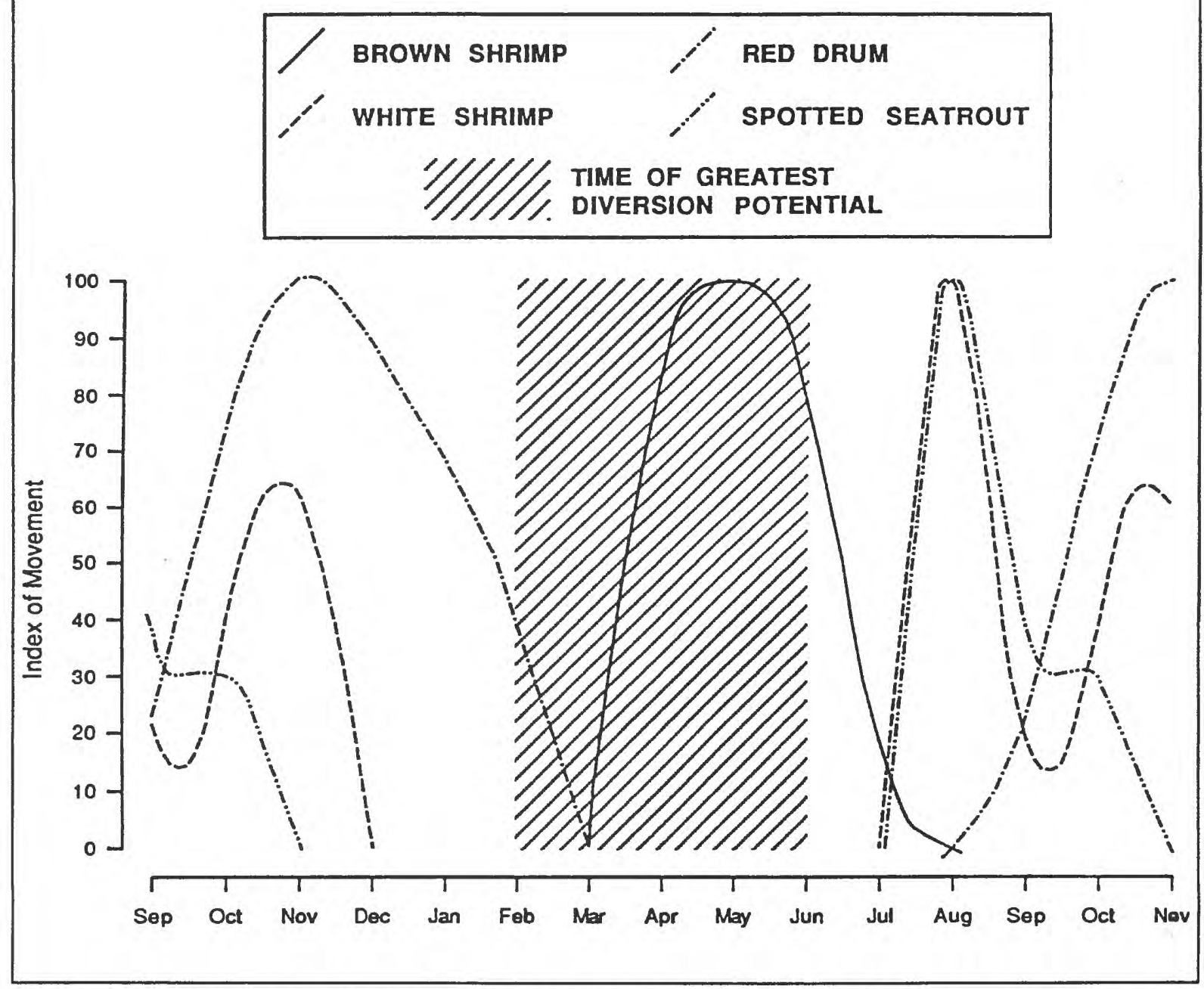

Figure 2-2. An index of temporal movement of commercially important estuarine fisheries species in relation to freshwater diversion potential (adapted from Herke and Rogers, 1988).

The fisheries aspects are well illustrated in the case of the recently completed Caernarvon structure which discharges into the upper end of the Breton Sound estuary. The Caernarvon freshwater diversion structure will be operated to produce optimal conditions for oyster production in the Breton Basin. Several factors lead to this decision, including the economic importance of the public oyster grounds and the fact that the region of suitable substrate conditions for the oysters is well established and cannot be feasibly moved in a landward or seaward direction. In the Breton Sound estuary, the American oyster (Crassostrea virginica) is the most economically important fisheries species. Not only is the harvest from the privately leased grounds substantial, but the seed oyster production on the state public grounds sustains the industry in the southeastern Barataria Basin and the southwestern Pontchartrain Basin as well.

Oyster production is controlled by substrate availability, temperature, salinity (Galtsoff, 1964; Tabony, 1972; Dugas, 1977), predation (Breithaupt and Dugas, 1979), and 
disease (Owen, 1955). A substantial effort has been made to maintain suitable substrate by applying shell and other culch material to the producing grounds in the Breton Sound Basin. On bottoms with suitable substrate and salinity greater than 15 parts per thousand (ppt) throughout the year, oyster production is limited by the pathogen Labyrinthomyxa marina and the predacious oyster drill (Thais haemostoma). It has been reported that the low salinity tolerance of oysters is $5 \mathrm{ppt}$ when temperatures exceed $20^{\circ} \mathrm{C}$ (Dugas and Perret, 1976). Below $20^{\circ} \mathrm{C}$, the oyster can close tightly and respire at a slow rate. According to Schechter (1943), oyster drills are immobilized at salinities of $10 \mathrm{ppt}$ and are killed by exposure to $7 \mathrm{ppt}$ for several weeks. More recently during the floods of 1983, Chatry and Millard (1986) observed oysters actively feeding at $3 \mathrm{ppt}$ and temperatures of $30^{\circ} \mathrm{C}$. Additionally, Chatry (personal communication, 1990) collected oyster drills in an area exhibiting $5 \mathrm{ppt}$ and temperatures of $25^{\circ} \mathrm{C}$ for three months. The oyster drills buried themselves in the mud to await more favorable conditions.

Oyster production can be directly related to freshwater inflow and salinity management. It is well established that production of seed oysters 2.5 to $7.6 \mathrm{~cm}$ ( 1 to 3 in) relates directly to the oyster harvest of the following year. Chatry, Dugas, and Easley (1983) related annual salinity regimes to seed oyster production at several monitoring sites on the public seed grounds for the period 1971-1981. The annual salinity data for sites where seed oyster populations exceeded 20 oysters $/ \mathrm{m}^{2}$ were pooled to compose a target annual salinity regime or "a good oyster year." Eight historical regimes qualified. These data are represented in Figure 2-3. The critical months are May through September. Salinities in May should range from 6 to $8 \mathrm{ppt}$, average $13 \mathrm{ppt}$ in June and July, and not increase to $15 \mathrm{ppt}$ until late August. September salinities should not average more than $20 \mathrm{ppt}$. These average monthly salinities were accepted as the proposed goal salinities with one exception. Model calculations indicated that residual freshwater in the system in May would preclude attainment of the higher goal salinities required in June (U.S. Army Corps of Engineers [USACE], 1986). The target annual regime was therefore smoothed as shown in Figure 2-3.

\section{Sediment Availability for Wetland Maintenance}

The sediment contribution to the wetlands by freshwater diversions depends on a number of elements, including the rate of water diversion, the sediment concentration of the diverted water, and the size distribution of the sediment. The clay fraction of the sediments suspended in the diverted water is the most important with regard to wetland maintenance because of the very slow water velocities expected to occur in the marsh. The sand fraction in most cases becomes a hindrance in the diversion delivery system, falling out rapidly and increasing maintenance requirements. Silts may be delivered to wetland areas and deposited along stream banks. However, resulting elevation of the stream banks will increasingly hinder input to interior wetlands through overbank flow. The following section evaluates each size fraction for an average water year.

The magnitude of freshwater diversion is determined primarily by the stage of the river, which is controlled by the discharge of the river at the diversion site at a particular time. To determine sediment availability, data concerning sediment concentration and river discharge were obtained. Three sites on the river have been sampled for total suspended sediment (TSS) and concomitant discharge in recent years: Tarbert Landing, St. Francisville, and Belle Chasse. This data set has been analyzed by Mossa (1988), who derived regression relationships for each site with discharge $(\log 10)$ as the independent 


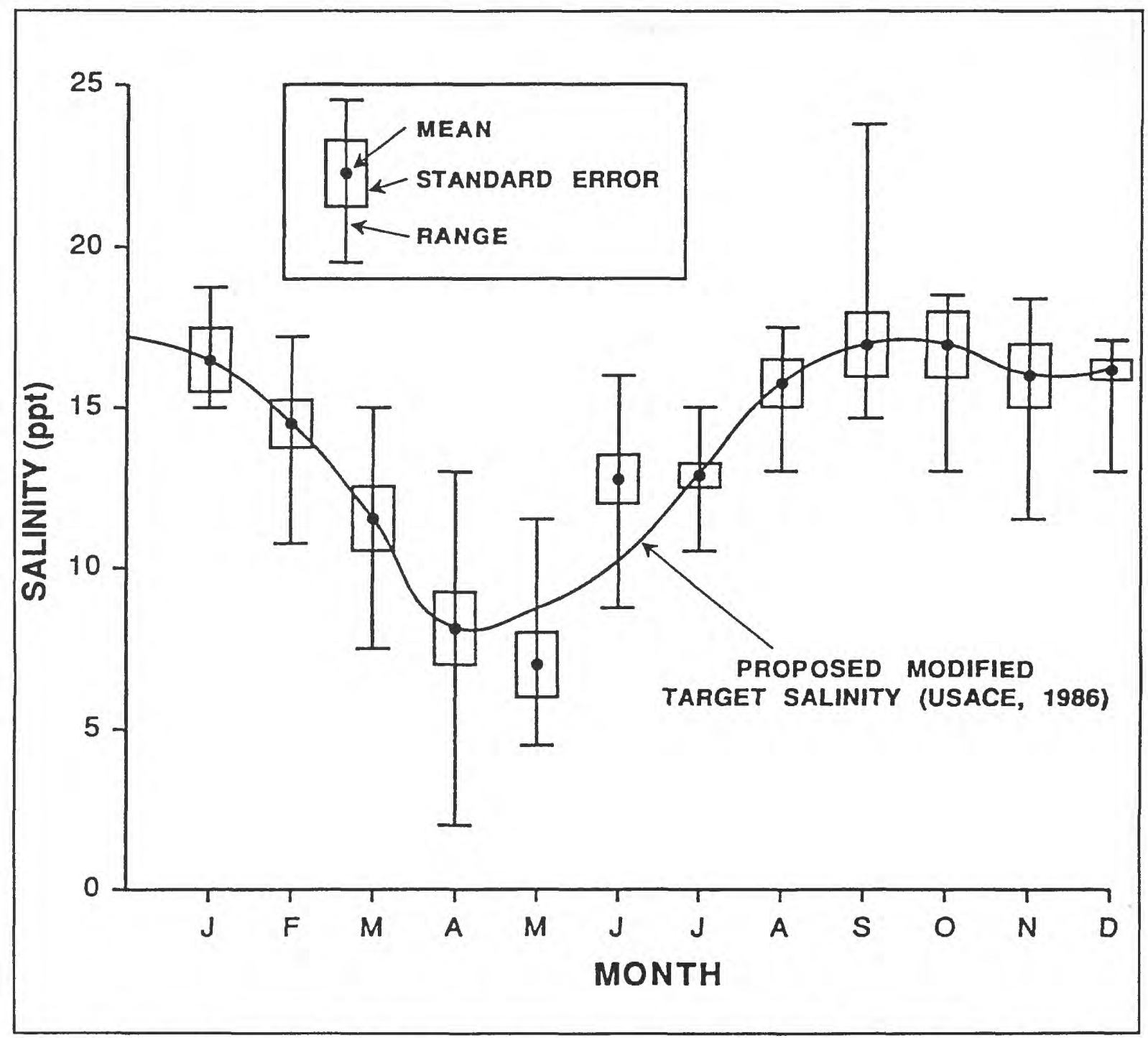

Figure 2-3. Mean monthly salinity, range, and standard error for good oyster years from stations on the public seed grounds in Breton Sound and modified target salinities for operation of the Caernarvon freshwater diversion structure.

variable and TSS $(\log 10)$, suspended silt-clay $(\log 10)$, suspended sand $(\log 10)$, suspended sediment $\operatorname{load}(\log 10)$, and percent sand as dependent variables.

The Belle Chasse sampling site is the only one within the zone of freshwater diversion feasibility. However, TSS is split into sand and silt-clay fractions only. Also, the data for Belle Chasse were not readily available. The Tarbert Landing data separated the clay from silt and sand; contained over 500 observations from 1972-1989; and was readily available on computer diskette from the Hydrology Section, New Orleans District, Army Corps of Engineers (USACE, 1990). The equations for Belle Chasse derived by Mossa (1988) were used to compute predicted values for TSS, silt-clay, and sand concentrations, using the discharge values from Tarbert Landing. The scatter plots of the actual data 
from Tarbert Landing and the predicted values for Belle Chasse are presented in Figure $2-4$.

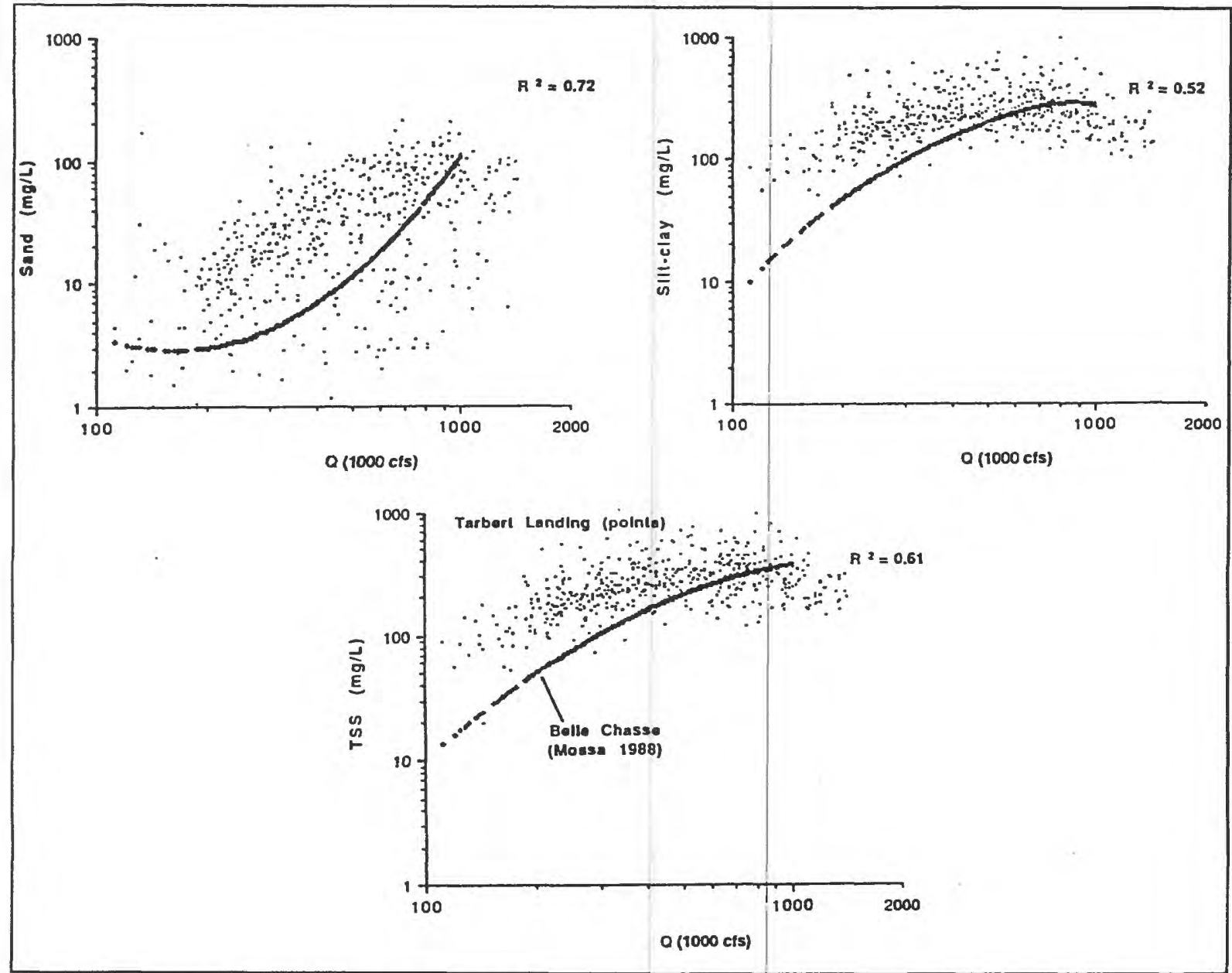

Figure 2-4. The relationships of Mississippi River discharge to total suspended sediment (TSS) and the sand and silt-clay fractions at Tarbert landing, 1972 1989 (USACE, 1990). The same relationships are shown for Belle Chasse using regression equations for Mossa (1988).

Total suspended sediment for Tarbert Landing generally increases gradually from about $60 \mathrm{mg} / \mathrm{L}$ at low discharges to $200-300 \mathrm{mg} / \mathrm{L}$ for discharges of approximately $11,330 \mathrm{cms}(400,000 \mathrm{cfs})$. Concentrations thereafter stay fairly uniform with little scatter, until discharges reach $25,480 \mathrm{cms}(900,000 \mathrm{cfs})$ when they begin to decrease. At Belle Chasse, concentrations are much lower at low discharge but rise to approximately the same level of $200 \mathrm{mg} / \mathrm{L}$ as Tarbert landing at $12,740 \mathrm{cms}(450,000 \mathrm{cfs})$. Concentrations continue to rise slowly and equal or exceed those of Tarbert Landing at peak flows (Figure 2-4).

The silt-clay fraction follows a very similar pattern as TSS at both sites, including a slight depletion at very high discharges. At intermediate and high discharges, the silt-clay concentrations of the two sites are very similar. For the sand fraction, the concentration at Tarbert Landing exhibits a high rate of increase with discharge, with 
much scatter. At Belle Chasse, there is almost no suspended sand until a threshold of $11,330 \mathrm{cms}(400,000 \mathrm{cfs})$ is reached. Above that, the concentration increases rapidly to over $100 \mathrm{mg} / \mathrm{L}$ at $28,300 \mathrm{cms}(1,000,000 \mathrm{cfs})$, indicating the TSS values at Belle Chasse that exceed those of Tarbert Landing at high discharge are related to the sand fraction (Figure 2-4).

Because the silt-clay concentrations at Tarbert Landing and Belle Chasse are somewhat similar at intermediate and high discharges, separate plots were made of silt and clay versus discharge for Tarbert Landing (Figure 2-5) to learn more about the probable clay distribution at Belle Chasse, within the freshwater diversion zone. The suspended clay concentration does not vary substantially with river discharge, and the data exhibit little scatter. Silt concentrations on the other hand exhibit the formerly described pattern of increasing with discharge to a plateau and decreasing at peak discharges (Figure 2-5). The substantial scatter suggests that other factors, such as hysteresis, may influence the distribution (Mossa, 1988). From this information, it is assumed that the clay concentrations at Tarbert Landing approximate those at Belle Chasse.

To relate the freshwater diversion scenario discussed above to sediment introduction for wetland maintenance, the data for Tarbert Landing were reduced to monthly means to be plotted by water year. Figure 2-6 presents the monthly mean and standard error for discharge and TSS. During the period from December to March, TSS concentration climbs from $275 \mathrm{mg} / \mathrm{L}$ to a peak of $340 \mathrm{mg} / \mathrm{L}$ at $19,800 \mathrm{cms}(700,000 \mathrm{cfs})$. At the higher discharges of April and May, TSS concentration decreases back to near $275 \mathrm{mg} / \mathrm{L}$. From the standpoint of marsh maintenance, the maximum sediment availability occurs from January through March. However, the particle size distribution must be considered. Figure 2-7 shows the monthly mean and standard error for the sand, silt, and clay concentrations at Tarbert Landing. During the same period, the clay concentration only varies from 130 to $150 \mathrm{mg} / \mathrm{L}$ and from 125 to $160 \mathrm{mg} / \mathrm{L}$ annually. The silt concentration increases from $95 \mathrm{mg} / \mathrm{L}$ in December to a peak of $125 \mathrm{mg} / \mathrm{L}$ in March and decreases substantially in April and May. Moving the peak diversion discharge to earlier in the year will not greatly affect clay input but would greatly enhance silt input to the wetlands. The sand concentration gradually increases from $50 \mathrm{mg} / \mathrm{L}$ to a peak of $65 \mathrm{mg} / \mathrm{L}$ in March at Tarbert Landing. However, the predicted sand concentration at Belle Chasse (Figure 2-7) exhibits a very pronounced peak of over $100 \mathrm{mg} / \mathrm{L}$ in April, the month when, presumably, the highest diversion discharge is planned (see Figure 2-3). This suggests that maximizing diversion in December through March may reduce adverse siltation and maintenance of the delivery system. 


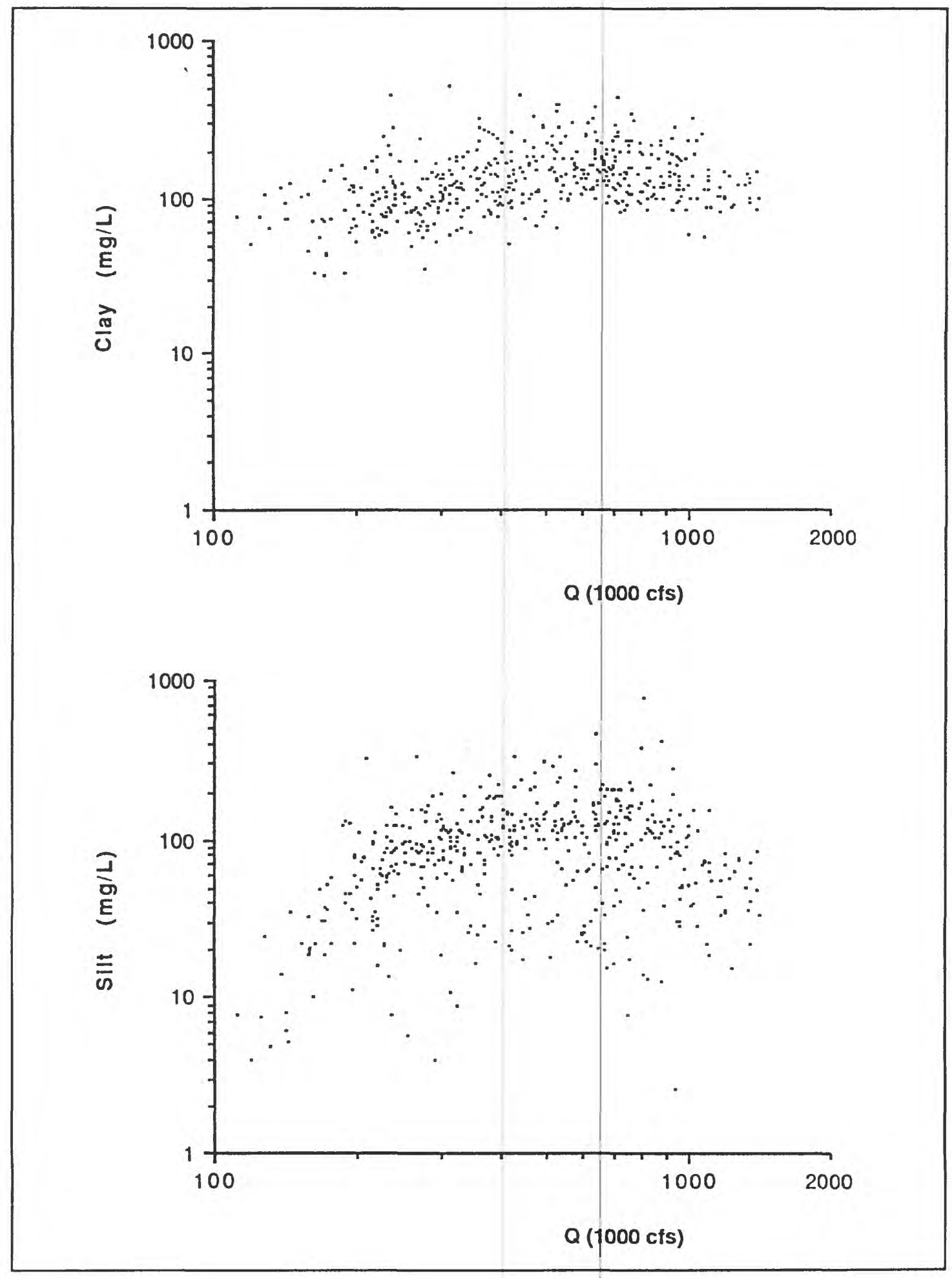

Figure 2-5. Relationships between Mississippi River discharge and the silt and clay fractions of the suspended sediment concentration for Tarbert Landing, 1972-1989 (USACE, 1990). 

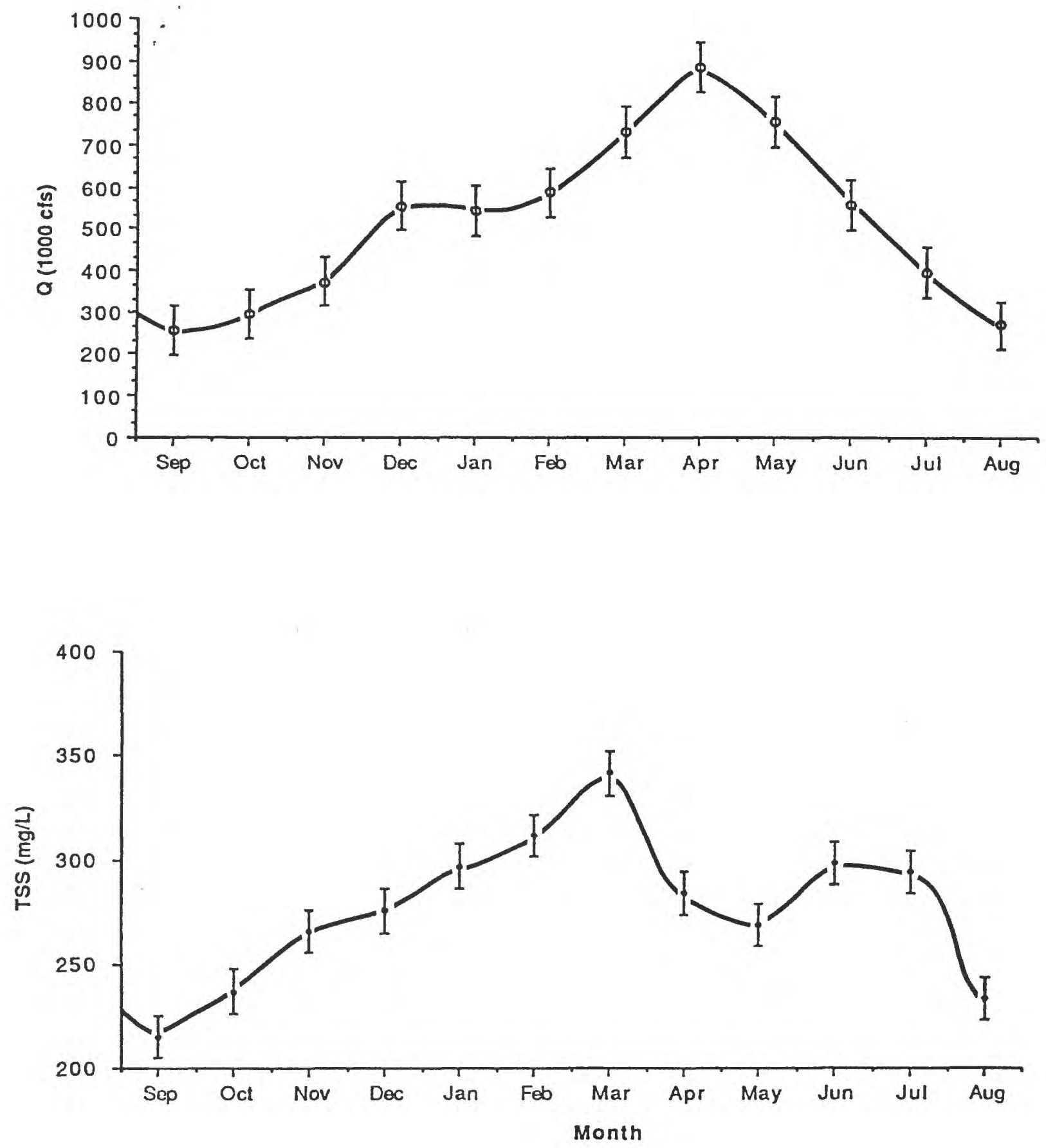

Figure 2-6. Monthly mean and standard error for discharge and total suspended sediment at Tarbert landing, 1972-1989 (USACE, 1990). 


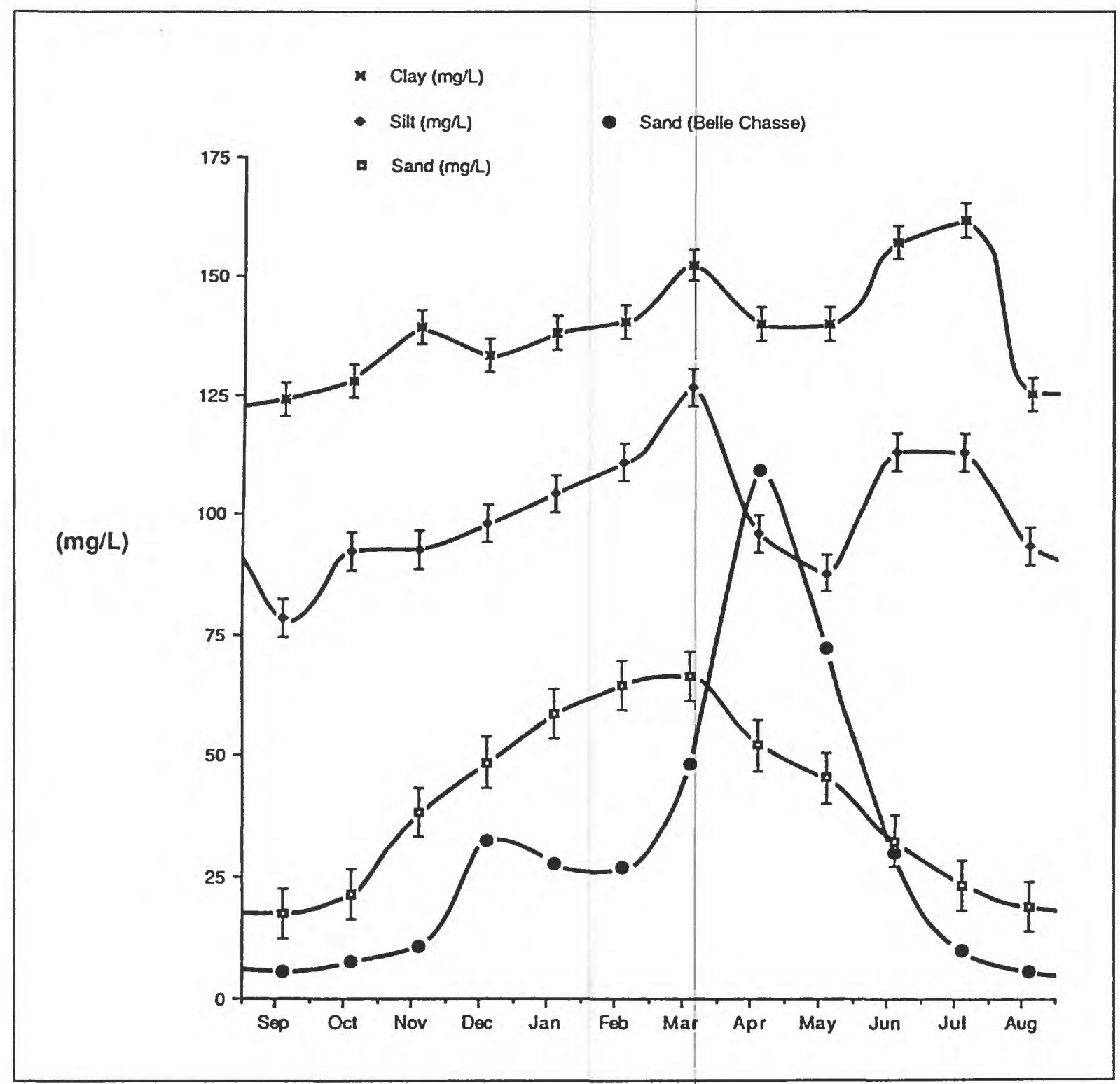

Figure 2-7. Monthly mean and standard error for sand, silt, and clay concentrations at Tarbert Landing, 1972-1989 (USACE, 1990), and predicted sand concentration at Belle Chasse (Mossa, 1988). 


\section{Operation for Wetland Maintenance}

The above findings are directly applicable to the recently completed Caernarvon Diversion Structure in the Breton Sound Basin and to the proposed Davis Pond structure in the Barataria Estuary. Both structures were justified on the basis of enhancement of oyster production, and proposed operational scenarios call for diversion to take place within the bounds of goal salinities related to that objective. Accordingly, benefits of the diverted water to the wetlands and wildlife of the upper basin will occur within the bounds of that salinity regime. However, in light of the sediment availability in the river, a closer look at the goal salinities is in order. As stated above the critical months for oyster recruitment are May to September (Chatry, Dugas, and Easley, 1983); the winter and early spring months with low temperatures are not. Also, populations of estuarine-dependent species are on the decline in the colder months, with the exception of the brown shrimp.

Diversion discharge can feasibly be increased from late December through March for the purpose of wetland maintenance without adversely impacting goal salinities for oysters (Figure 2-8). Water temperatures below $20^{\circ} \mathrm{C}$ from October to April allow oysters to withstand low salinity. By attaining peak discharges in December through March, a 24 percent increase in sediment delivery to the upper estuary would occur (Figure 2-6). The majority of the increase would be silt (Figure 2-7).

Since local rainfall is usually high in the spring and residual freshwater has been cited as a problem in attaining higher goal salinities in June and July, the time of peak diversion discharge should cease by the end of March, allowing two months for calibration of the gate openings to meet the goal salinities for June and July (Figure 2-8). This scenario would reduce the diversion need in April, the time of peak flow in the river, thereby precluding the introduction of high sand loads that contribute to higher maintenance costs of the delivery and distribution system. 


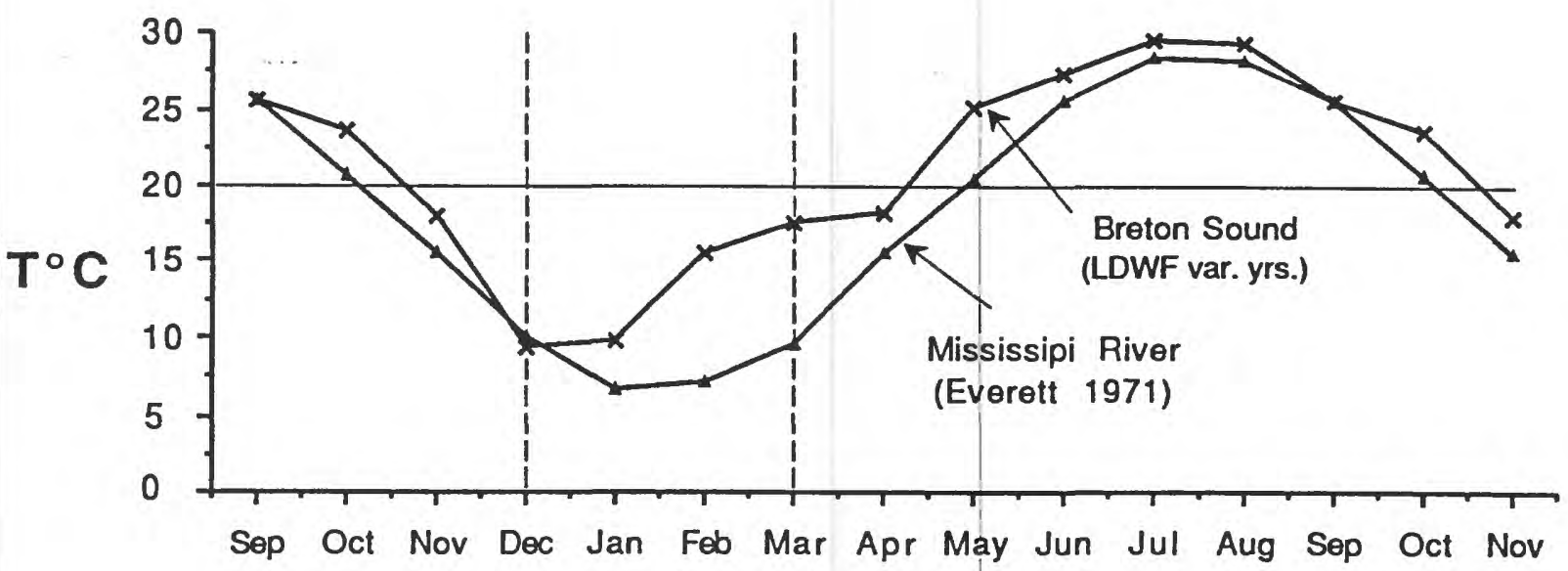

FT

(NGVD)
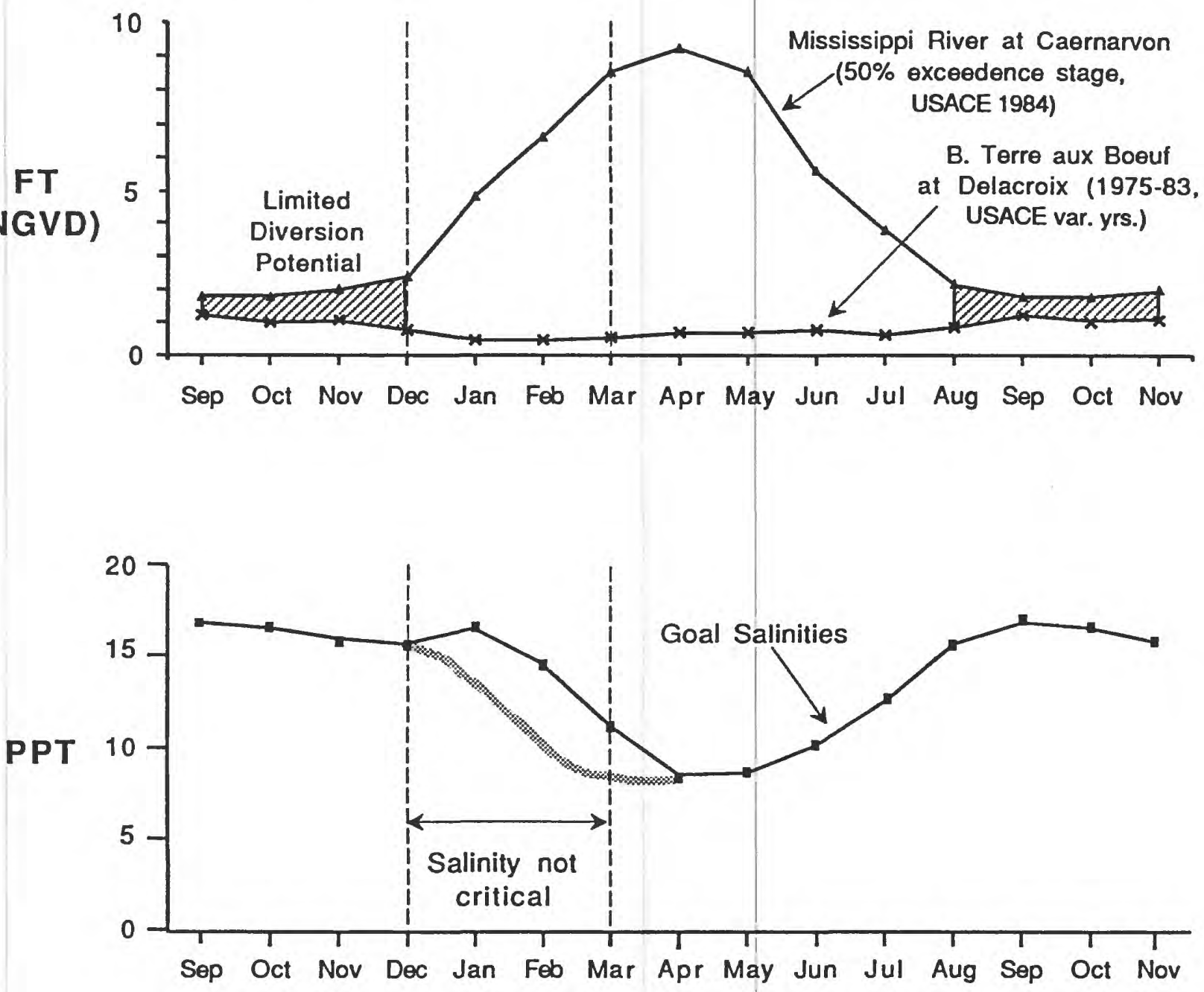

Figure 2-8. Critical temperatures and stages in the Mississippi River and Breton Sound in comparison with goal salinities of the Caernarvon freshwater diversion project. 


\section{CHAPTER 3}

\section{FIELD STUDY OF THE WHITE'S DITCH SIPHON}

\section{Description of the Study Area}

The White's Ditch Siphon is located on the east side of the Mississippi River at river mile 64.4 Above Head of Passes (AHP) in Plaquemines Parish, Louisiana (Figure 3-1). The siphon was constructed in 1963 by Plaquemines Parish for the specific purpose of increasing the production of muskrats for commercial trapping. The muskrat populations were to be increased by increasing the productivity and diversity of marsh plants through the fertilizing effects of the river water. In fact, for decades prior to the raising of the levees along the river, small siphons had been used in this area for irrigation and rice cultivation. The White's Ditch Siphon is composed of two, 1.27-m (50-in) diameter, steel pipes extending $244 \mathrm{~m}$ (800 ft) from the river to the Belair Canal. The design discharge is $7.1 \mathrm{cms}$ ( $250 \mathrm{cfs}$ ). However, in 1972, a project to raise the river levees required modification of the siphon and reduced its efficiency.

The White's Ditch siphon discharges into a semi-confined subbasin within the Breton Sound estuary. This subbasin is formed by the natural levee ridges of River aux Chenes to the east and the Mississippi River levee to the west (Figure 3-1) and will hereafter be referred to as the River aux Chenes subbasin. River aux Chenes (Oak River) is an abandoned Mississippi River distributary. Part of the siphon outfall is routed across the subbasin through the Belair Canal and into River aux Chenes. The Belair Canal separates the enclosed northern and the open southern part of the subbasin. River aux Chenes provides for water exchange between the River aux Chenes subbasin and the main portion of the Breton Sound estuary. Much of this exchange occurs through Shell Bayou, which connects River aux Chenes with Spanish Lake and the remainder of the basin. Shell Bayou also serves as a hydrologic connection between Spanish Lake and wetlands immediately to the east of River aux Chenes. Water exchange between these wetlands and Spanish Lake is served by the Manuel Canal (Figures 3-1 and 3-2).

The setting of the study area (Figure 3-1) also illustrates the possible value of siphons as a supplemental diversion to larger structures. The natural levee ridges of River aux Chenes separate the subbasin to the east from the outfall of the Caernarvon diversion structure so that benefits will be only indirect through tidal exchange rather than through direct input. With some modification of the Belair Canal banks, the White's Ditch Siphon could contribute to the River aux Chenes subbasin in a manner similar to that in which the Caernarvon structure serves the Breton Sound Basin.

\section{Methods and Materials}

Field studies and experiments were designed to provide information on the delivery and distribution of freshwater and sediment from the White's Ditch Siphon in the River aux Chenes subbasin and to evaluate the effects of the freshwater and sediment on marsh maintenance in the River aux Chenes subbasin through comparison with a similar area not influenced by the siphon discharge. The locations and types of data acquisition are shown in Figure 3-2. The areas selected for comparison are located along the Belair Canal and the Manuel Canal respectively. Because the Caernarvon structure has not yet been operated, the Manuel Canal site did not receive water or sediment from that source. 


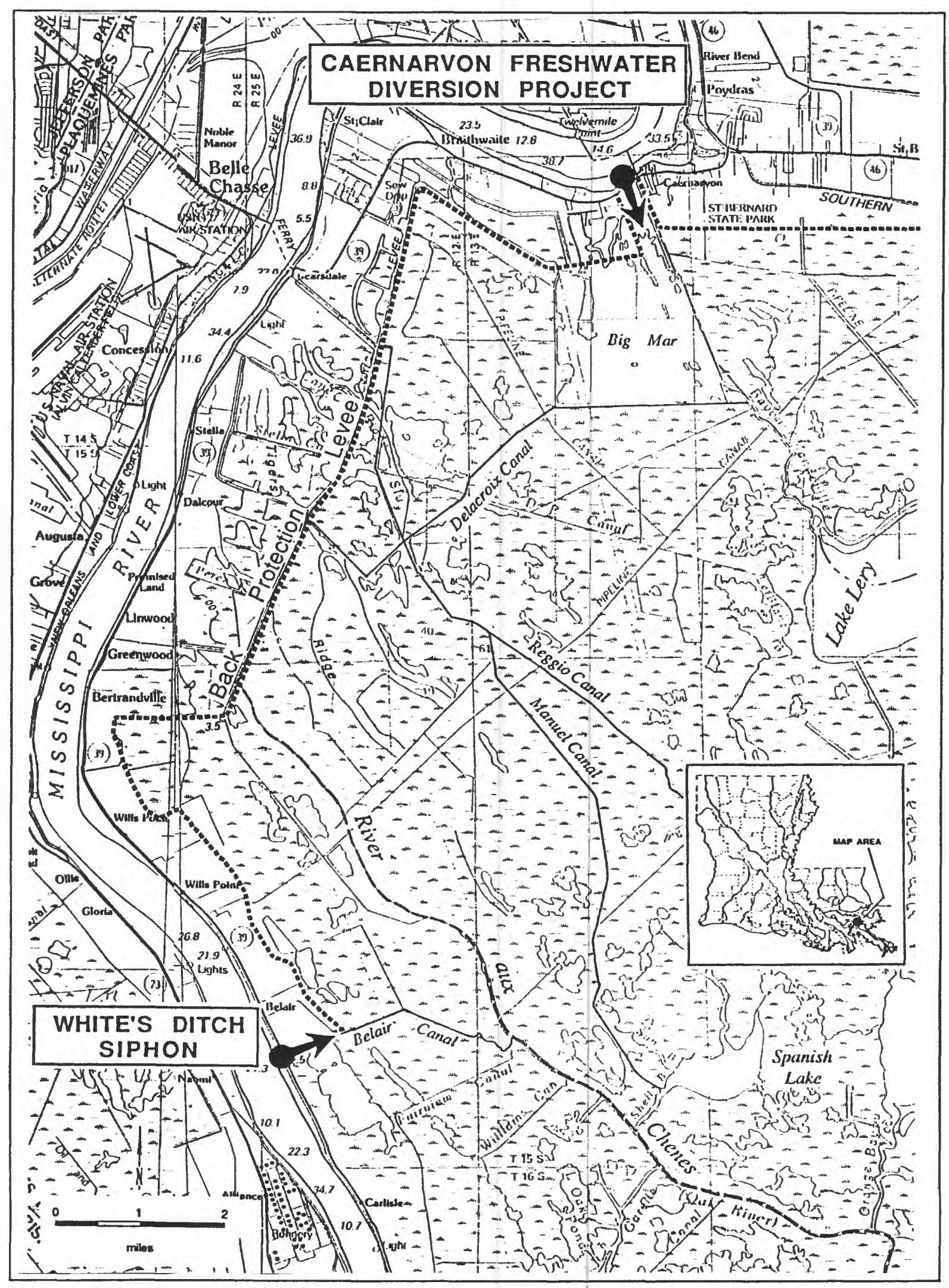

Figure 3-1. Regional setting of the study area. 


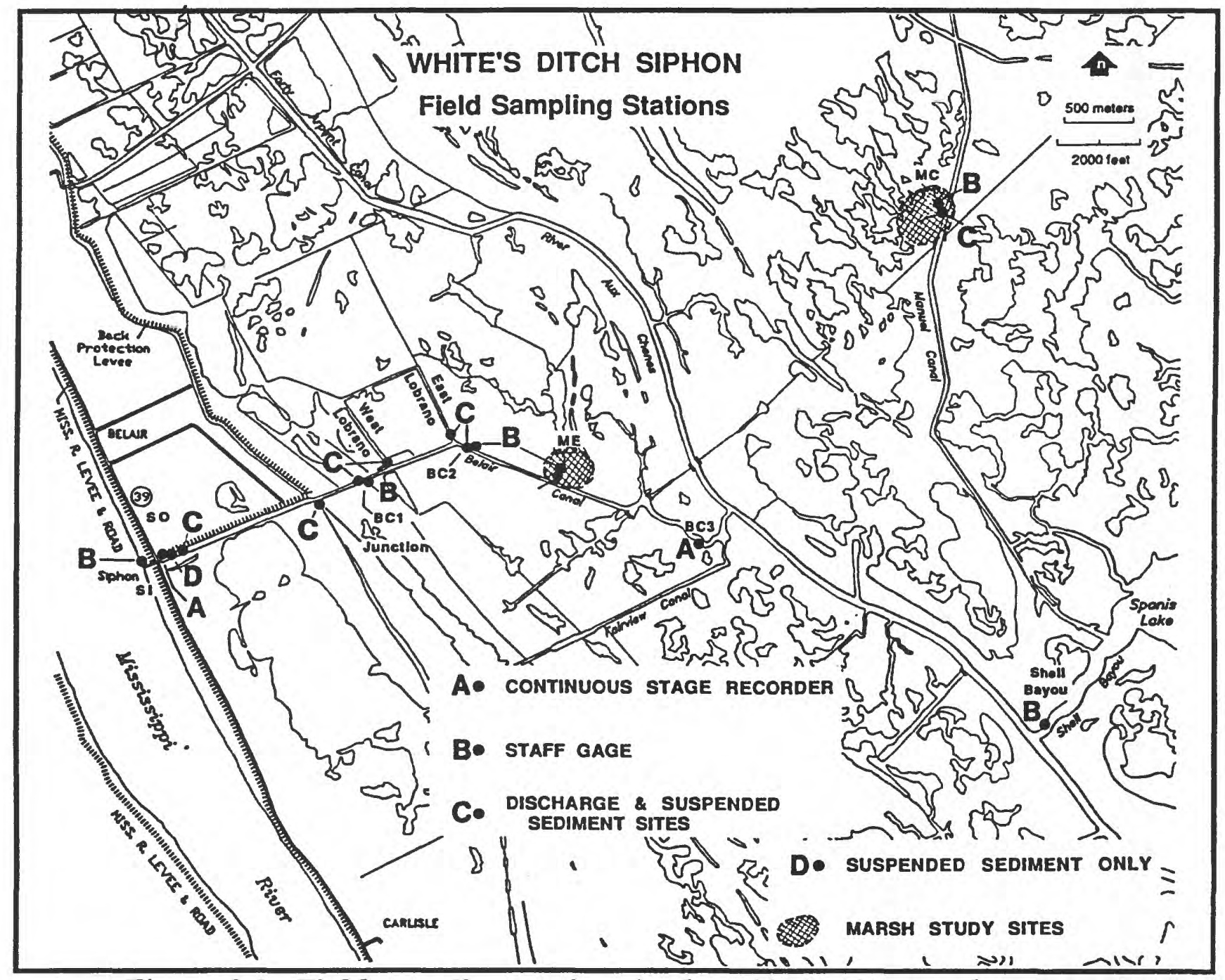

Figure 3-2. Field sampling stations in the White's Ditch study area.

\section{River Stages and Tidal Conditions}

Field investigation of the project area was initiated on October 28, 1989. A bathymetric survey and observations of the banklines and hydrological connections were made and sampling locations selected. On January 10 and 11, 1990, staff gages and continuous water level recorders were installed. Vertical control at the siphon outfall point in the Belair Canal was obtained from an existing staff gage, calibrated to National Geodetic Vertical Datum (NGVD). This datum was transferred across the Mississippi River levee, using an automatic level and tripod, and a staff gage was erected at the siphon intake in the river. Adjacent to the existing staff gage in the outfall canal, a Stevens Model 68 Type F water level recorder was installed.

Three additional staff gages and another water level recorder were installed at locations downstream from the siphon outfall, as shown on Figure 3-2. These were calibrated to average marsh level (van Beek and others, 1984). At each site, ten marsh elevations were averaged and compared to the existing water level to set the staffs and recorder. At a low tide following a frontal passage on January 13, a horizontal water 
level was assumed to exist in the Belair Canal, and the gage elevations were estimated relative to the NGVD datum. Charts from the recording gages were retrieved monthly. Daily stages for the Mississippi River at Carollton and Alliance were obtained from the New Orleans District, USACE, to construct a record for the staff gage at the siphon intake.

\section{Water and Sediment Discharge}

Operation of the White's Ditch Siphon for the 1989-90 water year was initiated on January 26, 1990. Following this event, a series of water and sediment discharge determinations were made at the sites shown on Figure 3-2. Flow and sediment data were collected on February 20, April 25, May 25, and June 20, corresponding to the rising phase of predicted spring tides during those days. These tidal conditions were selected because they are most likely to force water from the Manuel Canal into adjacent wetlands. On each trip, the cross-sectional area was determined at each location. Average current velocities at a number of locations within each cross section were determined from sets of readings taken at $0.2,0.6$, and 0.8 of the depth using a Marsh-McBirney Model 201 velocity meter.

Suspended sediment samples were taken using a model US DH-59 depth-integrating sampler. Sediment samples were analyzed by vacuum filtration onto a pre-dried, pre-weighed filter $(0.47 \mathrm{micron})$. The filters were oven dried and weighed to the nearest $0.1 \mathrm{mg}$.

\section{Bottom Sediment Fractions}

A series of eleven $0.6-\mathrm{m}$ (2-ft) core-samples of bottom sediments were taken at distances ranging from $53 \mathrm{~m}$ (175 ft) to $2,700 \mathrm{~m}$ (9000 ft) from the siphon outfall in the Belair Canal. The cores were longitudinally sectioned in the laboratory and examined; selected cores were photographed. From three of the cores integrated, subsamples were take over the entire $0.61-\mathrm{m}$ length of each core. These were analyzed for sand, silt, and clay components using methods described by Folk (1968). For the remainder of the cores, the top $5 \mathrm{~cm}$ were subsampled and analyzed as above.

\section{Areal Extent of Freshwater and Sediment Dispersion into Wetlands}

Conditions where a combination of southerly winds and rising tides disperses diverted freshwater and sediments into the marshes were observed on April 25, 1990. To observe and document the distribution patterns, both aerial reconnaissance and ground observations were used. On the morning of April 26, an aerial overflight of the outfall area was made. Sediment plumes were photographed and mapped. Within several hours of the overflight, an airboat was used to visit 21 marsh locations in the outfall area within the River aux Chenes subbasin and in the control area adjacent to the Manuel Canal. Twenty-one marsh water samples and 15 marsh soil samples were obtained. Water temperature and salinity readings were made at 4 marsh pond sites and 16 channel sites to determine relative influence of siphon water and estuarine water. Temperature and salinity readings and a water sample were taken also at the siphon outfall point to characterize the diverted river water.

In the laboratory, water samples were vacuum-filtered and analyzed, as discussed earlier. Marsh soil subsamples were dried and weighed, then combusted to remove 
organic matter and reweighed. The values were used to calculate percent mineral content of the dry weight. The data were then plotted on maps of the area for interpretation.

\section{Effects of Diversion On Wetland Accretion}

To collect data on the effects of freshwater diversion on wetland accretion, two marsh study sites were selected (Figure 3-2). A site where introduction of water and sediment into the marsh from the Belair Canal occurs was chosen as a marsh experimental area (ME). A similar hydrologic setting was found on the Manuel Canal for a marsh control area (MC) where the chances for siphon influence were remote. Three separate methods were employed in each area: surface soil analysis, direct measurement of accretion, and experiments with sediment trapping devices.

The marsh study was initiated on January 11, 1990, prior to the opening of the siphon. After installation of the sampling equipment at ME, the marsh was burned as a wildlife management measure. To prevent bias in the study, the MC site was also burned in similar fashion.

A set of three soil cores were taken at each of three locations, $1 \mathrm{~m}, 30 \mathrm{~m}$, and $100 \mathrm{~m}$, respectively, from the edge of the streambanks at both the ME and MC sites (a total of 18 cores). The water level was immediately below the marsh floor during the sampling. The core samples were transferred to preweighed ziplock bags. In the laboratory, the bagged samples were weighed, transferred to metal bowls, dried at $80^{\circ} \mathrm{C}$ for 24 hours, and the total dried sample was reweighed. Subsamples were taken and combusted at $500^{\circ} \mathrm{C}$ for 1 hour to remove organic matter. The mineral matter remaining was then weighed. Percent water, percent organic, percent mineral, specific density, and bulk density were calculated.

Marker horizons of feldspar were created at 1, 30, and $100 \mathrm{~m}$ from the edge of the streambanks at ME and MC, parallel to the soil core sites. For each of the six sites, approximately $13.5 \mathrm{~kg}$ (30 lbs) of white feldspar powder was evenly spread over a $1-\mathrm{m}^{2}$ area to a thickness of approximately $10 \mathrm{~mm}$. On July 20 (162 days later), each of the sites was subsampled using a $6.3-\mathrm{cm}$ diameter coring device. Direct measurements of accretion in millimeters were made at 10 locations around the circumference of 3 subsamples at each site (30 observations).

The third and final element of the marsh studies involved placement of preweighed ceramic sediment traps at 1,30 , and $100 \mathrm{~m}$ from the edge of the streambanks at ME and $\mathrm{MC}$, parallel to the other sites. A trap consists of a $9.5 \times 9.5 \mathrm{~cm}$ ceramic plate with eight 9-cm vertical members attached to it (Figure 3-3). The average weight of a clean trap is approximately $180 \mathrm{~g}$. Twelve traps were set out at each of the three distances at the ME and MC sites on January 11. Sets of four traps were retrieved on April 16 (94 days), June 20 (159 days), and August 16 (226 days). In the laboratory, the traps were oven-dried at $70^{\circ} \mathrm{C}$ for 24 hours and weighed to the nearest $0.1 \mathrm{~g}$. The traps were then subjected to $500^{\circ} \mathrm{C}$ for one hour to combust all organic matter and reweighed. For each trap, grams dry weight of organic and mineral sediment accumulation was calculated. Analyses of variance were performed to test for the significance of treatment (experimental vs control), distance from streambank, and duration of activity. 

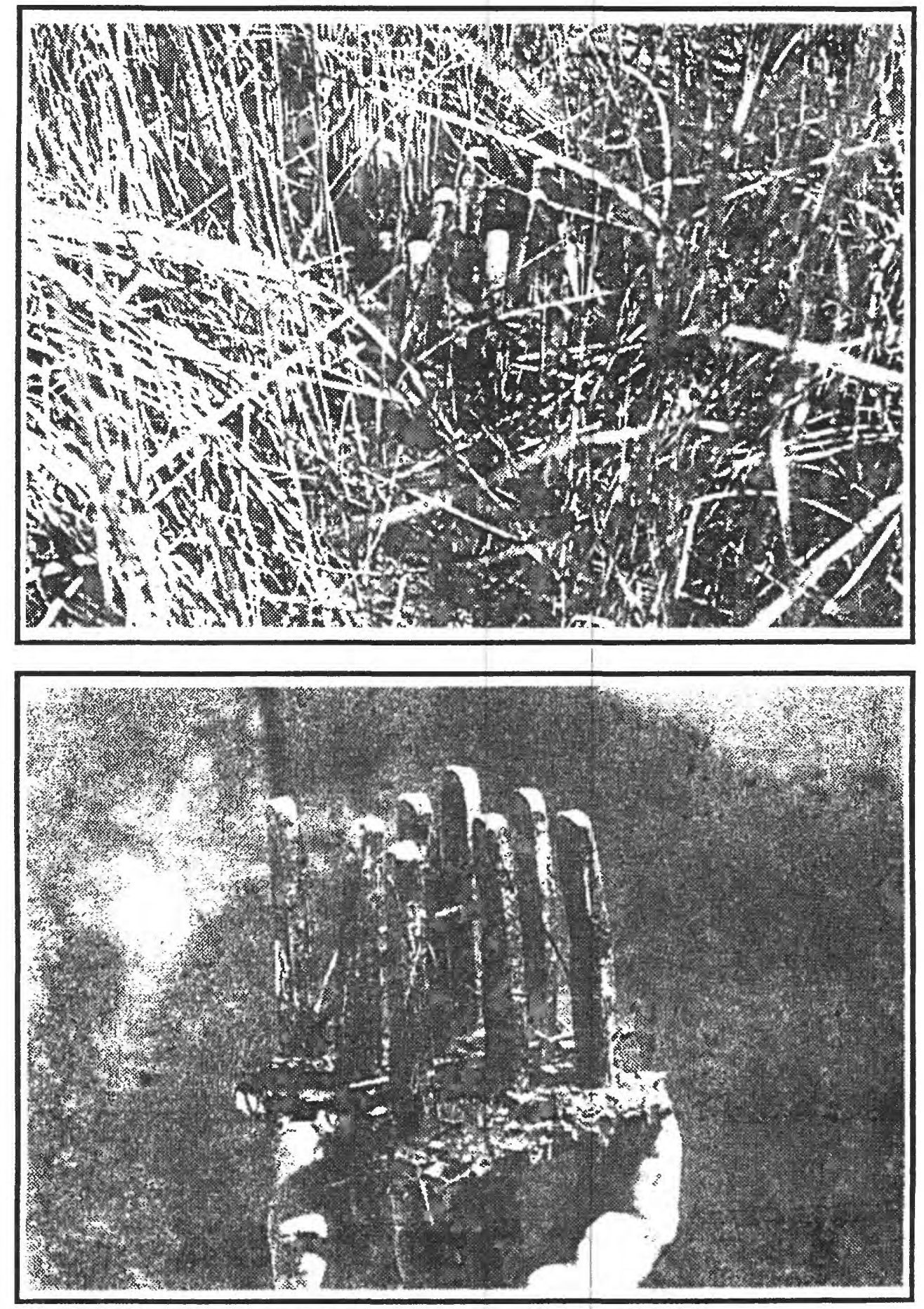

Figure 3-3. Views of the ceramic sediment traps in place before the marsh burn at ME (above) and on retrieval (below). 


\section{Results and Discussion}

\section{River Stages and Tidal Conditions}

Daily data from the Mississippi River at Carrollton (New Orleans) and Alliance were obtained for January through August 1990 from the New Orleans District, U.S. Army Corps of Engineers. Readings made at the siphon intake staff gage (SI) over the study period were regressed with corresponding values for Carrollton and Alliance. The equation with the Alliance gage, $1.61 \mathrm{~km}(1.9 \mathrm{mi})$ downstream, as the independent variable showed a slope of 1.15 , intercept of -1.16 , and $R$-square of 0.995 . Carrollton showed a slope of 0.57 , intercept of 0.521 , and R-square of 0.990 . Since there were missing values for Alliance, the Carrollton equation and data were used to create a daily record for SI (Figure 3-4). The hydrograph shape is bimodal, with one flood crest at about $2.7 \mathrm{~m}(9 \mathrm{ft})$ NGVD in early March and a second slightly higher peak in June. While peak flow occurs normally in April, the bimodal pattern is typical for the Mississippi River and relates to timing of rainfall and snow melt in the Ohio and Missouri basins. Usually the second crest is of smaller magnitude than the first.

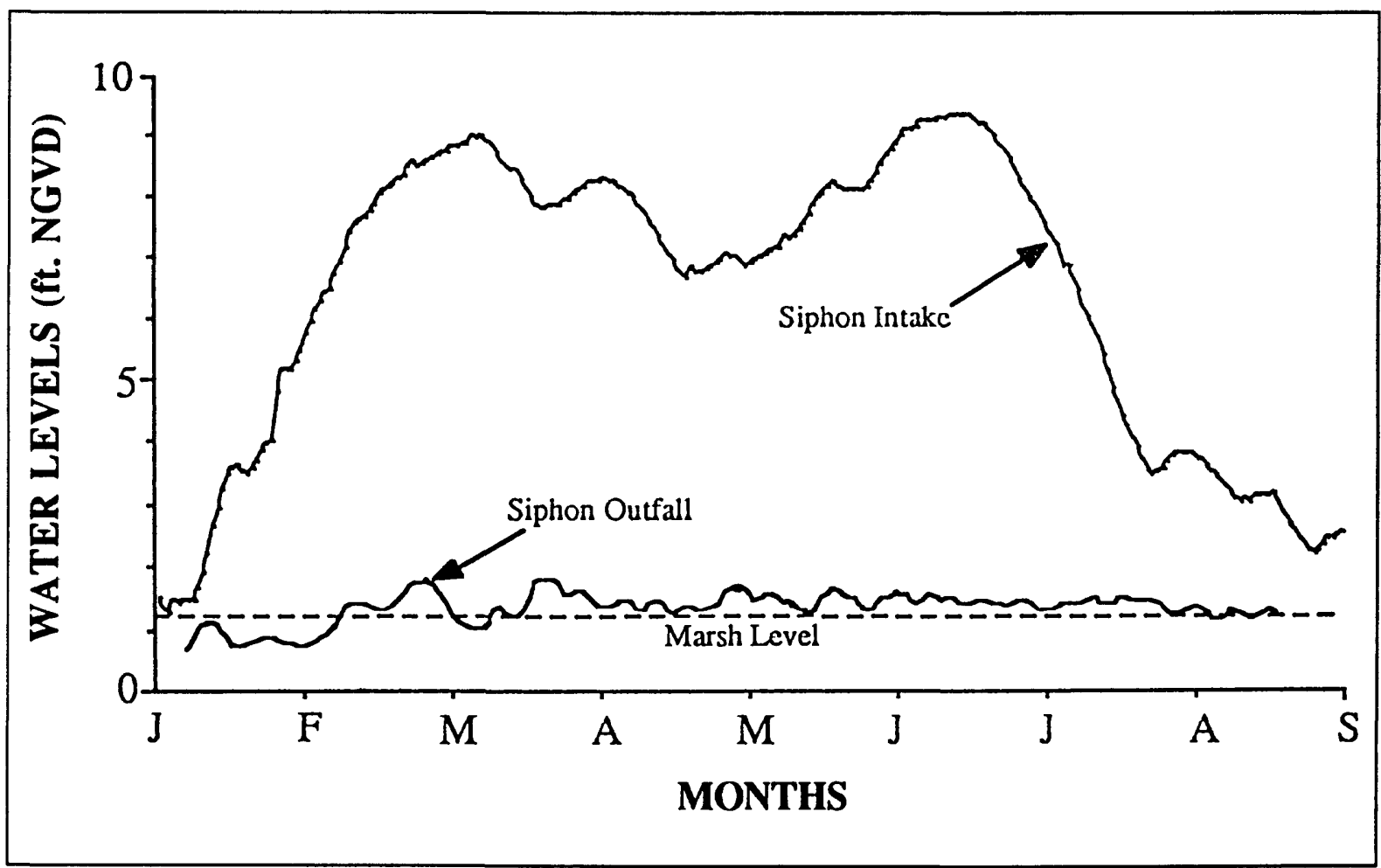

Figure 3-4. Mississippi River stages at the siphon intake and tidal stages at the siphon outfall from January through August 1990.

Also shown in Figure 3-4 are the average daily stages at the siphon outfall. Average marsh level was calculated to be $+0.36 \mathrm{~m}(+1.2 \mathrm{ft})$ NGVD. The diagram gives the magnitude of the hydraulic head between the river and the outfall area and shows that the river stage governs the diversion potential. Wind-induced tidal variations related to frontal passage in February and March changed the hydraulic head by only about $20 \%$.

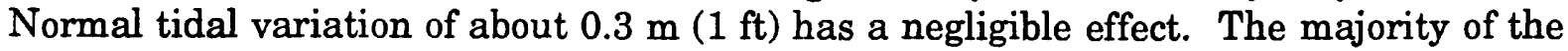
time, changing tidal conditions do not greatly alter the diversion potential. When the 
siphon ceased to flow on July 27 , the river stage was at $1.16 \mathrm{~m}(3.8 \mathrm{ft})$ and the tidal stage was at $0.46 \mathrm{~m}(1.5 \mathrm{ft})$, resulting in $0.7 \mathrm{~m}(2.3 \mathrm{ft})$ of head. Computations, as discussed below, suggest that there was still a potential for $2.8 \mathrm{cms}(100 \mathrm{cfs})$ of discharge. Personal communication with the operators of the siphon indicate that at low river stages, water drawdown from passage of ships in the river introduce air to the intake, breaking the suction of the siphon.

Continuous recordings of water levels in the siphon outfall (SO) and the lower end of the Belair Canal (BC3) are displayed in Figure 3-5 along with a record of the sampling events and siphon operation. Before the opening of the siphon on January 26, the water levels of the two sites closely coincide. The same occurs during the period of April 9-23 and after August 27 when the siphon was closed. During siphon operation, a surface-water gradient is maintained along the Belair Canal, being most pronounced when the tide falls rapidly at BC3. The pattern of water-level fluctuation is dominated by wind events produced by the passage of low pressure systems. Strong winds from the south and east quadrants precede the systems and cause a rise in basin water levels. After passage of the system, winds from the north and west quadrants push waters seaward and water levels recede regionally. The records show at least nine of these events. Six events occurred while the siphon was running and water levels exceeded marsh level. Water and sediment discharge measurements were taken on the rising leg of three of those events (Figure 3-5).

\section{Water and Sediment Discharge}

Water and sediment from near the surface of the Mississippi River is discharged from the White's Ditch Siphon into the upper end of the Belair Canal (Figure 3-2). The Belair Canal runs generally eastward and intersects the remnants of a natural bayou before entering River Aux Chenes. Belair Canal is morphologically divided into three major segments. Examples of the channel cross sections for these segments are shown in Figure 3-6, the stations where water and sediment discharge measurements were made.

From the siphon outfall to the Junction (see Figure 3-2), the canal is wide and shallow. The canal was initially widened to provide material for a flood protection levee. Sediment from the siphon continues to infill the channel and Plaquemines Parish periodically dredges this segment. From the Junction to the East Lobrano Canal (see Figure 3-2), the Belair Canal is narrow and confined between high, steep banks (Figure 3-6, Station BC1). In this section, the first opportunity for distribution of diverted water into the marshes occurs, not through overbank sheetflow but through three smaller channels (the Junction, West Lobrano, and East Lobrano Canals). The final segment of the Belair Canal to River Aux Chenes (Figure 3-6, Station BC2) has low banks, and although there are some sections displaying sparse shrub vegetation (indicative of former spoil disposal), much of the bank is characterized by streambank marsh where overbank flow occurs. An area adjacent to a small tidal channel that connects to the Belair Canal in such a marsh segment was chosen as the experimental marsh site (Figures 3-2 and 3-6, Station ME).

The Manuel Canal, a major water conduit, enters the study area from the north ending at Shell Bayou near Spanish Lake (Figure 3-2). Banks along this canal are elevated by 15 to $25 \mathrm{~cm}$ (6 to 10 in) as a result of spoil deposition at the time of construction, and water exchange between the marsh and the canal during normal tidal 

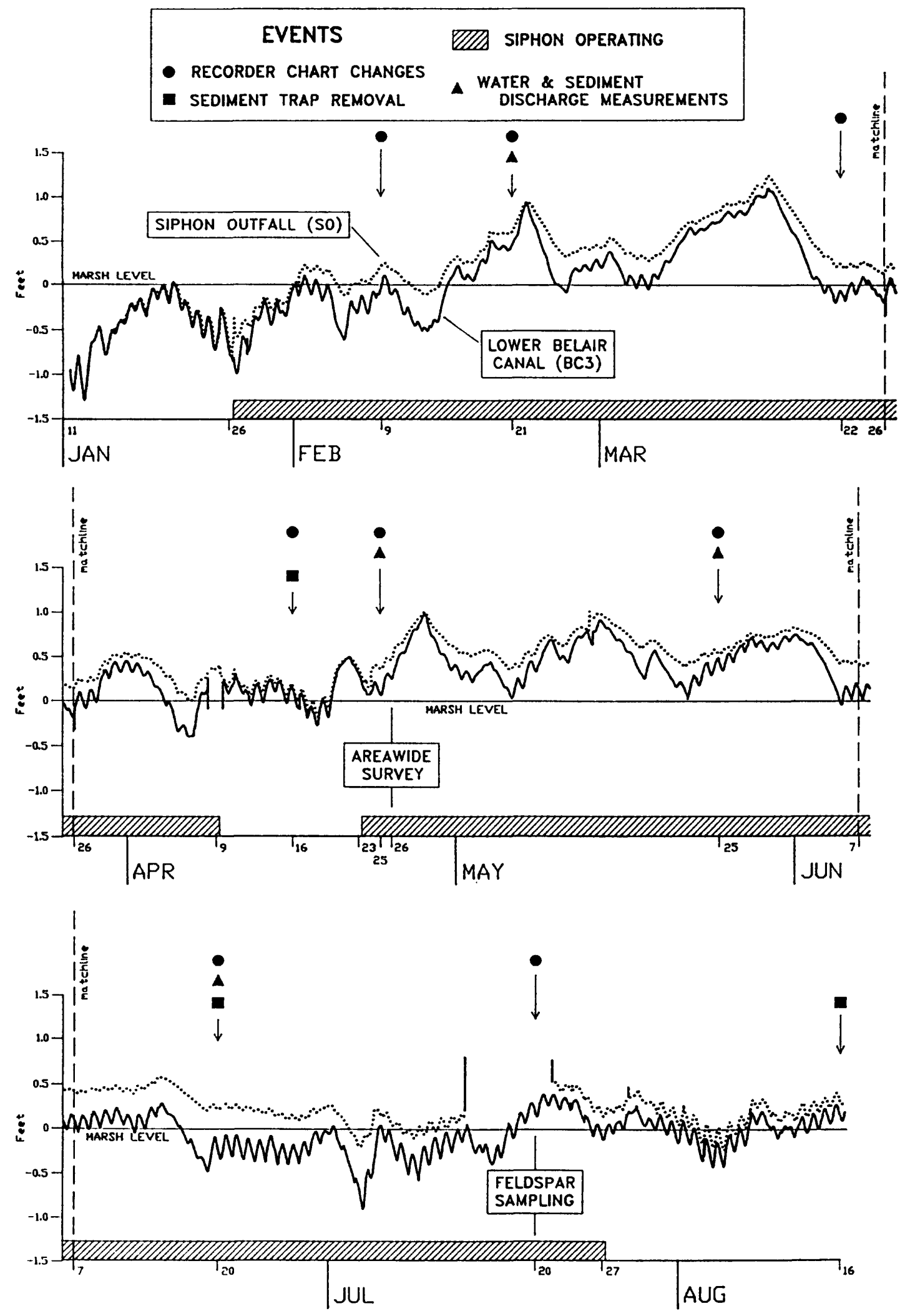

Figure 3-5. Continuous water-level records in the Belair Canal, periods of siphon operation, and sampling events. 


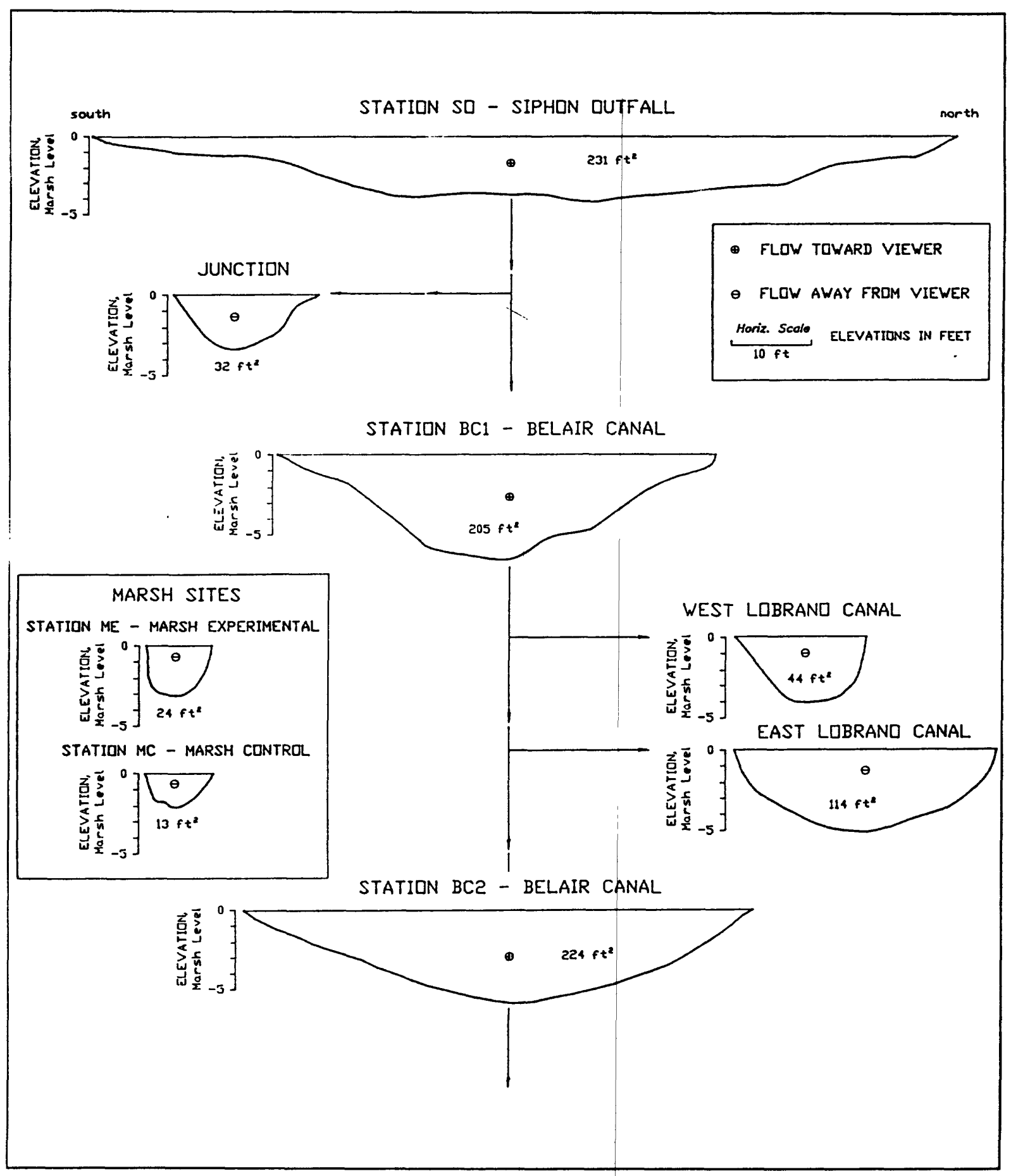

Figure 3-6. Channel cross-section profiles at discharge measurement sites.

conditions occurs primarily through small cuts in the spoil bank. Marsh surrounding one of those cuts was chosen as the control marsh site (Figures 3-2 and 3-6, Station MC).

The stations shown on Figure 3-6 were occupied four times during the 1990 diversion season. The data on flow velocity and suspended sediment concentration are presented in Appendix A. Sediment concentration of the diverted water at the outfall point was 
determined from three vertically integrated samples, obtained at a distance of $30.5 \mathrm{~m}$ $(100 \mathrm{ft}$ ) from the siphon discharge point. This location was within the outfall scour pool where turbulence prevents sediment from being deposited. Siphon discharge was determined at a distance of $183 \mathrm{~m}$ (600 ft) from the siphon where flow had normalized; suspended load was collected again at this point. Figure 3-7 shows the relationships of discharge and sediment concentration with distance downstream for the times of measurement. Total sediment concentrations were $230,178,184$, and $102 \mathrm{mg} / \mathrm{L}$ for February, April, May, and June, respectively. Water discharges were 4.76, 4.93, 2.18, and $6.29 \mathrm{cms}(168,174,183$, and $222 \mathrm{cfs})$ for the same periods, respectively. These values are consistent with the earlier reported observations that the highest sediment concentrations in the river occur at the lower diversion potential and diminish at the higher end of the diversion potential. While this may be expected to result in an equalization of diverted sediment discharge, the product of concentration and diverted water discharge, this was not the case for the White's Ditch Siphon in this study. The measured suspended sediment load discharges were 1092, 875, 953, and $640 \mathrm{~g} / \mathrm{sec}(104,83,91$, and 61 tons/day) for February, April, May, and June, respectively. Using the data above, with the siphon operating for 170 days, it was computed that 70.3 million $\mathrm{m}^{3}(57,000 \mathrm{ac}-\mathrm{ft})$ of freshwater and 12 million $\mathrm{kg}$ (13,200 tons) of sediment were diverted through the White's Ditch Siphon.

A series of flow diagrams were constructed to display the distribution of water and sediment measured during the four field investigations (Figure 3-8). The values in rectangles are computed water discharge (cms) and sediment discharge $(\mathrm{g} / \mathrm{sec})$ at each station. Values in rounded rectangles are losses or gains not accounted for in the data and represent measurement error for the discharge and a combination of measurement error and sediment deposition/entrainment for the suspended load, as indicated in Figure 3-7. The loss of sediment within the first $183 \mathrm{~m}(600 \mathrm{ft})$ increased from $40 \mathrm{~g} / \mathrm{sec}$ in February to $240 \mathrm{~g} / \mathrm{sec}$ in May. This reflects a coarsening of the suspended load in the river and the proportionally greater deposition because of this in the outfall canal. Much of the high February concentration is probably fine silt (see Figures 2-5 and 2-7) that does not fall out of suspension until the East obrano station (Figure 3-7). In June, during the peak discharge of the year, the gain of $38 \mathrm{~g} / \mathrm{sec}$ may indicate entrainment of sediment in the upper end of the canal and eastward transport. During the first three sets of measurements, the regional water level was rising when observations were made. In June, the regional water levels were falling. It is believed that resuspension and transport of silt downstream occurs under these conditions, as indicated by bottom core-samples to be discussed below.

The three marsh distributaries (East Lobrano, West Lobrano, Junction) received 85 percent of the water and 55 percent of the sediment in February, and nearly 100 percent of the water and 41 percent of the sediment in April. In May, water levels had remained 0.15 to $0.30 \mathrm{~m}$ ( 0.5 to $1.0 \mathrm{ft}$ ) above marsh level for more than 30 days prior to the readings, and water levels were rising. There was still positive flow from the siphon in the Belair Canal, but only 21 percent of the water and 11 percent of the sediment were entering the marsh distributaries. About 55 percent of the water and 27 percent of the sediment were transported downstream in the canal in spite of rising tides. This can be partially explained by conditions that we have termed the "basin effect," which is the effect of the water levels within a given basin on water exchange between that basin and an adjacent water body. 


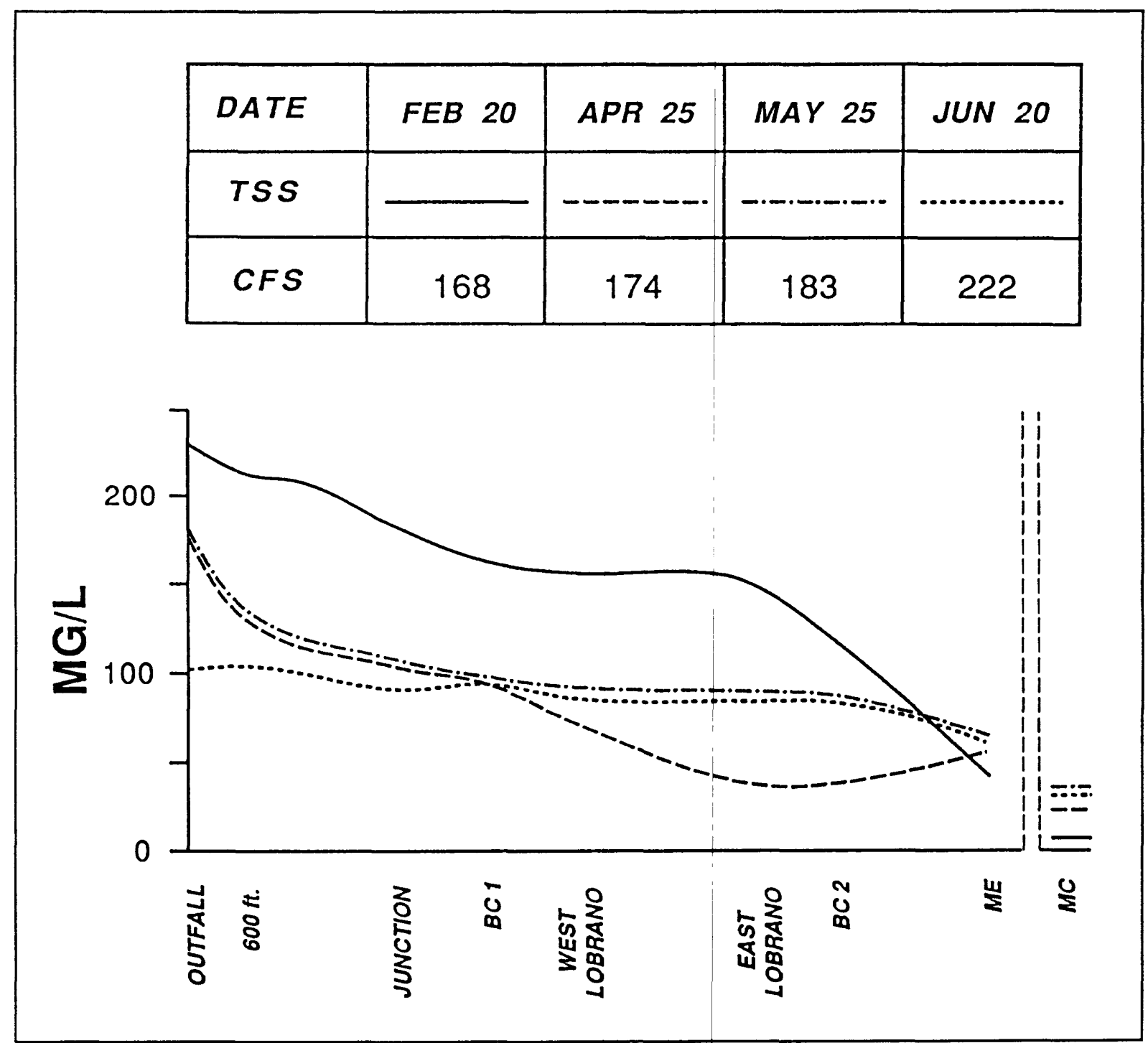

Figure 3-7. Discharge (cfs) and change in total suspended sediment (TSS) distribution downstream during the four sampling events.

The marsh areas receiving water from the Belair Canal are hydrologically defined by levees, spoil banks, and distributary ridges. The areas are filled and drained by the distributaries and Belair Canal. Once these marsh areas are filled with diverted water, additional input ceases and the discharge down the canal increases (Figure 3-8). By June, the major wind events had subsided and the highest diversion discharges occurred. Without the wind influence, only the daily $9 \mathrm{~cm}(0.3-\mathrm{ft})$ astronomical tidal range was active to drain and fill the marsh basins (Figure 3-5). Only 29 percent of the water and 24 percent of the sediment was measured entering the marsh distributaries on a rising tide.

The results given above must be viewed in the context of the net losses (or gains) that are unaccounted for in the measurements. For water discharge these values are -15 percent, +14 percent, -24 percent, and +8 percent for February, April, May, and June, respectively. The differences are attributable to a combination of measurement error and 


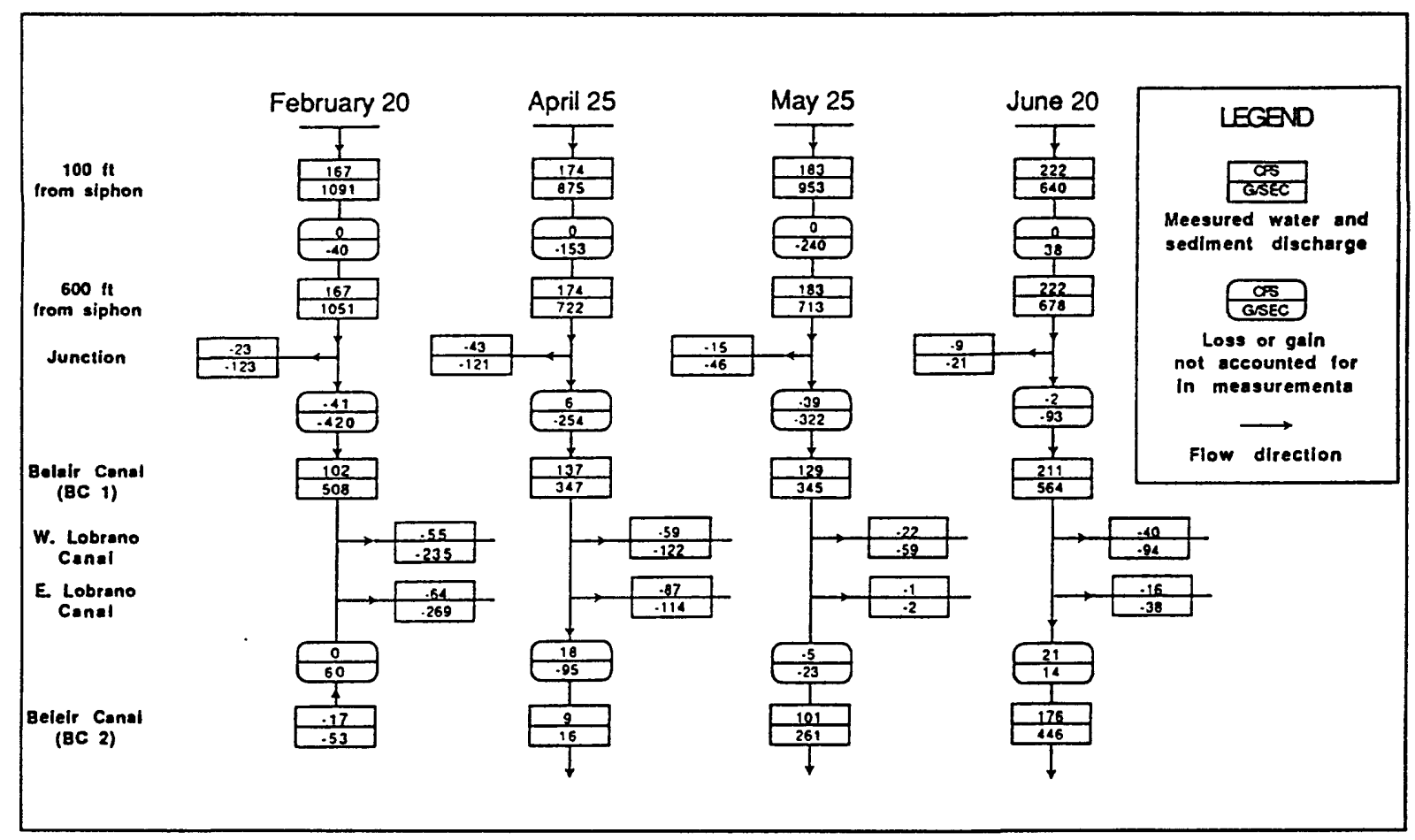

Figure 3-8. Flow diagrams showing the distribution of water and sediment at the discharge measurement sites.

inflow or outflow at two small cuts that were not measured. For sediment discharge, the values are -42 percent, -40 percent, -36 percent, and -12 percent for February, April, May, and June, respectively. Causes of these discrepancies include water discharge error, error in sampling and measuring sediment concentration, and sedimentation or resuspension occurring in the Belair Canal. However, the consistently high losses indicate that the main cause is sedimentation in the Belair Canal.

A final result of the diversion discharge measurements is the rating of the performance of the White's Ditch Siphon. The water discharge values measured at the siphon outfall (SO), the river stage, and the tidal stage were used in the standard weir equation to solve for the coefficient $\mathrm{C}$ (Table 3-1). The $\mathrm{C}$ value takes into account all of the frictional factors that reduce pipe flow such as obstructions, roughness, bends, and constrictions. Table 3-1 shows that the value of $\mathrm{C}$ for the siphon is about 0.3 or that 30 percent of the theoretical discharge is being delivered. This exercise also indicates, by the consistency of the $\mathrm{C}$ values, that the discharge measurements are reasonably accurate.

The performance of freshwater diversion siphons in general should not be judged by the output of the White's Ditch Siphon in 1990 during which the siphon delivered a maximum of $6.23 \mathrm{cms}(220 \mathrm{cfs})$ at higher than average river stage. The two $1.27-\mathrm{m}$ (50-in) diameter pipes were installed in 1963 at a cost of $\$ 100,000$ and at that time delivered $7.08 \mathrm{cms}(250 \mathrm{cfs})$ at normal high water, with a friction coefficient of about 0.6 (J. Tocho, personal communication). The apparent reduction in efficiency is believed to have resulted from a 1972 structural modification to accommodate upgrading of the Mississippi River levee. 

Table 3-1. Estimation of the C Factor in the Standard Weir Equation from Emperical Data on the White's Ditch Siphon.
$\mathrm{Q}=(\mathrm{C})(\mathrm{A})(2 \mathrm{~g}[\mathrm{Smr}-\mathrm{St}])^{\wedge} 0.5$
$\mathrm{C}=$ the factor accounting for head loss due to frictional forces in the system (value from 0 to 1 ).
$A=$ cross-sectional area of flow (two 50 -in pipes $=27.27 \mathrm{sq} \mathrm{ft}$ )
$\mathrm{g}=$ acceleration due to gravity.
$\mathrm{Smr}=$ stage in the Mississippi River ( $\mathrm{ft}$ ).
$\mathrm{St}=$ stage in the tidal outfall area $(\mathrm{ft})$.
$Q=$ the discharge (measured in cubic feet per second).

\begin{tabular}{|c|c|c|c|c|}
\hline DATE & $\begin{array}{c}\text { MEASURED } \\
\text { DISCHARGE }\end{array}$ & $\begin{array}{c}\text { RIVER } \\
\text { STAGE }\end{array}$ & $\begin{array}{c}\text { TIDAL } \\
\text { STAGE }\end{array}$ & $\begin{array}{c}\text { C } \\
\text { VALUE }\end{array}$ \\
\hline Feb-20 & 167.5 & 8.1 & 1.80 & 0.305 \\
\hline Apr-25 & 174.0 & 7.1 & 1.82 & 0.346 \\
\hline May-25 & 183.0 & 8.4 & 1.77 & 0.325 \\
\hline Jun-20 & 221.8 & 9.3 & 1.45 & 0.362 \\
\hline
\end{tabular}

\section{Bottom Sediment Fractions}

The upper section of the Belair Canal, from the outfall of the siphon to the end of the Back Protection Levee, has a history of maintenance dredging, thus indicating that sediment from the siphon is being deposited in the canal. Bottom core-samples were taken to determine deposition from suspension for each sediment fraction (Figure 3-9). Both surface samples and deeper integrated samples were analyzed. The first sample nearest the siphon was taken on the crest of a bar that defines the downstream limit of the outfall scour pool and rises to within $0.61 \mathrm{~m}(2 \mathrm{ft})$ of the water surface. The next four samples were taken down the slip face of the bar with the slope ending at about $1.2 \mathrm{~m}$ $(4 \mathrm{ft})$ deep. Surface samples show the percent sand generally decreasing from 80 to 90 percent at the crest to around 30 percent at the bottom of the slope. Continuing along the canal, the surface sediments are predominantly silts with minor amounts of sand and clay.

The surface samples display very recent conditions in the system. The canal has not been dredged for several years, and the cross section has nearly adjusted to the siphon discharge. The cross sections shown on Figure 3-6 indicate that the maintained end of the canal is only slightly larger than the lower sections, and Figure 3-8 shows the silty character of the channel bottom all the way to the site ME (see Figure 3-2). The clay fraction is not readily deposited in the present canal bottom. As mentioned earlier, entrainment and transport of silt probably occurs during high siphon discharge in combination with regional falling water levels.

The samples integrated over a $0.6-\mathrm{m}$ (2-ft) depth give an indication of sedimentation patterns over a longer period (Figure 3-9). The percent sand decreases with distance from the siphon, as would be expected. The silt fraction ranges from 50 to 70 percent. The 
most striking difference is the 40 percent clay content in the integrated sample near the West Lobrano Canal as compared to 5 percent for the surface sample. Apparently, more clay is being transported down the canal now than over the long-term.

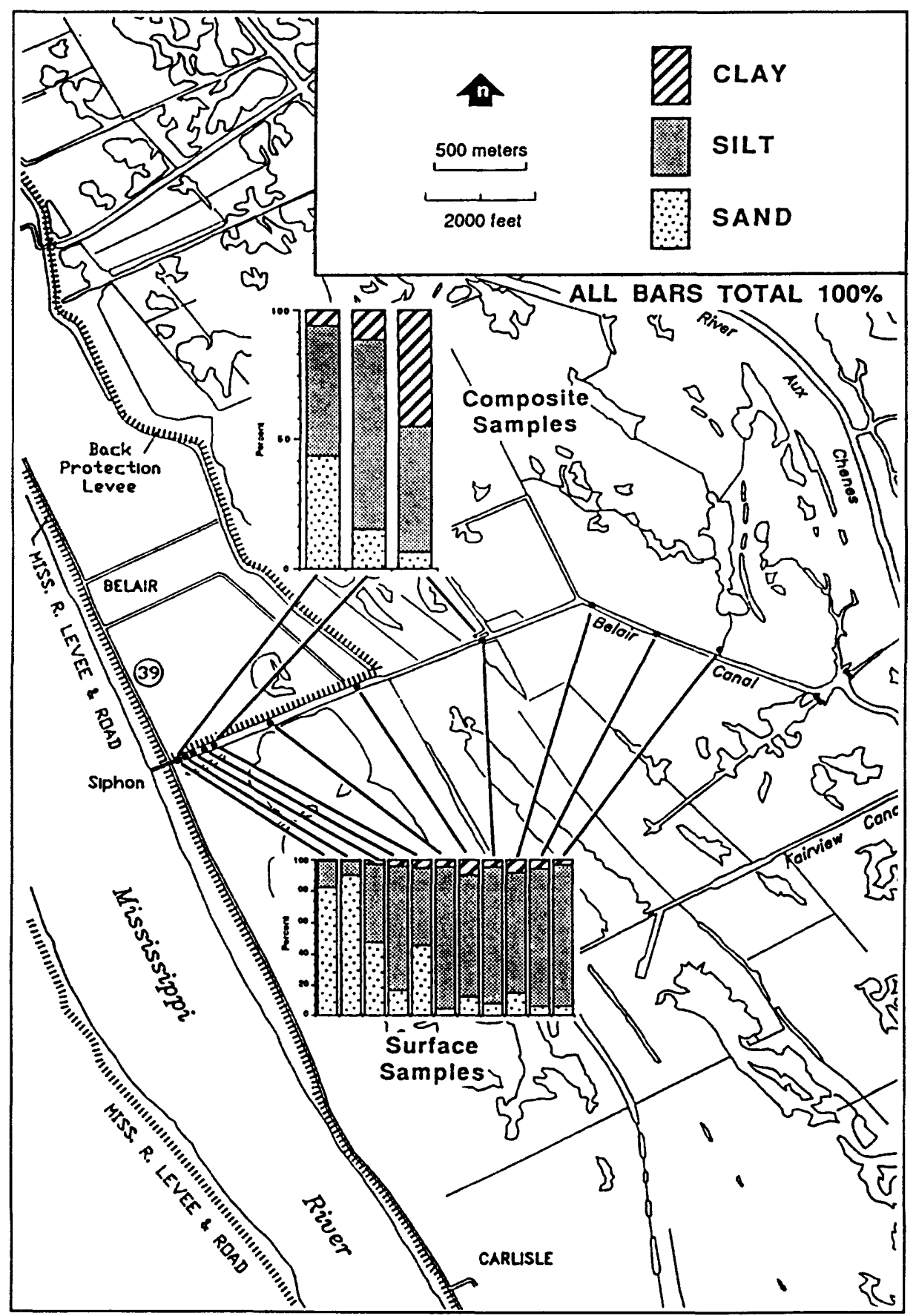

Figure 3-9. Grain-size components of bottom sediment cores from surface samples $(5 \mathrm{~cm})$ and composite samples $(62$ cm) in the Belair Canal. 


\section{Extent of Diversion Into Wetlands}

Early in the project, it was noted that the major southerly and easterly wind events produced the maximum input of water into the marsh through distributaries and overbank flooding. Such conditions were initiated on April 26, and the following discussion of results pertains to this event (Figure 3-5).

The aerial overflight did not reveal very distinguishable plumes of turbid water. The color of the ambient water was a slightly darker tan as opposed to the light tan of the full strength siphon water. In several shallow ponds on either side of the Belair Canal, a light streaking was noted for subsequent ground observation.

An airboat was used to make measurements in marsh areas of interest noted from the air. The observed distribution of water temperature and salinity in the area's water bodies is shown in Figure 3-10. Following the Belair Canal from the siphon to River Aux Chenes, there was an initial warming of the water to about $19^{\circ} \mathrm{C}$ with the salinity remaining low. Salinities were highest in the River aux Chenes and the Manuel Canal, reflecting the estuarine source. The highest salinity was $4.2 \mathrm{ppt}$ in River Aux Chenes. This water mass was mixing with the siphon water and progressing northward. The cooler siphon water was sinking under the brackish water mass. Mixed water was observed in the Fairview Canal. Siphon water entering the East and West Lobrano Canals was mixing with warmer, more brackish waters as it moved into the marshes. Relatively warm water with a salinity of $3.3 \mathrm{ppt}$ occupied the marsh ponds in the northern part of the area near River aux Chenes.

Marsh water samples were taken for determination of suspended sediment concentration (Figure 3-11). The TSS of pure siphon water was measured at $98 \mathrm{mg} / \mathrm{L}$. The highest values in the marsh were 25 to $34 \mathrm{mg} / \mathrm{L}$ and were associated with small ditches and micro-drainage features, such as animal trails. Interior marshes generally had values of 4 to $8 \mathrm{mg} / \mathrm{L}$ and were not directly connected to ditches or canals via micro-drainage features. At the marsh experimental ME site to be discussed later, samples were taken at the streambank, at $30 \mathrm{~m}$, and at $100 \mathrm{~m}$ during conditions of overbank flow, giving values of 18,5 , and $4 \mathrm{mg} / \mathrm{L}$, respectively. At the $\mathrm{MC}$ site, va'ues at streambank, $30 \mathrm{~m}$, and $100 \mathrm{~m}$, were 7,5 , and $5 \mathrm{mg} / \mathrm{L}$, respectively (Figure $3-11$ ).

At some marsh locations, surface-soil grab-samples were taken to measure the mineral content on a dry weight basis (Figure 3-12). The values show relative input of mineral sediment over an unknown period of time. Again, the higher mineral values in the 70 percent range occur only on the edges of connected drainage features, with the lowest values at interior marsh locations.

\section{Effects of Diversion on Wetland Accretion}

Field studies on the effec. of wetland accretion were carried out at the ME and the MC sites (Figure 3-2). At tive beginning of the study in January, both sites were dominated by thick growths of Spartina patens (wiregrass). Several months after the burning of the marsh, Scirpus olneyii (three-cornered grass) emerged at both sites and was quite abundant at MC. At ME, a variety of fresh and intermediate marsh plants became established along the streamside, including Cyperus odoratus (fragrant flatsedge), Bacopa monnieri (coastal waterhyssop), Setaria magna (Giant foxtail), and Vigna luteola (deer pea). Interior marshes at ME were dominated by wiregrass with some 
three-cornered grass. By August, the vegetation at both sites had grown to 0.7-1.0 $\mathrm{m}$ in height.

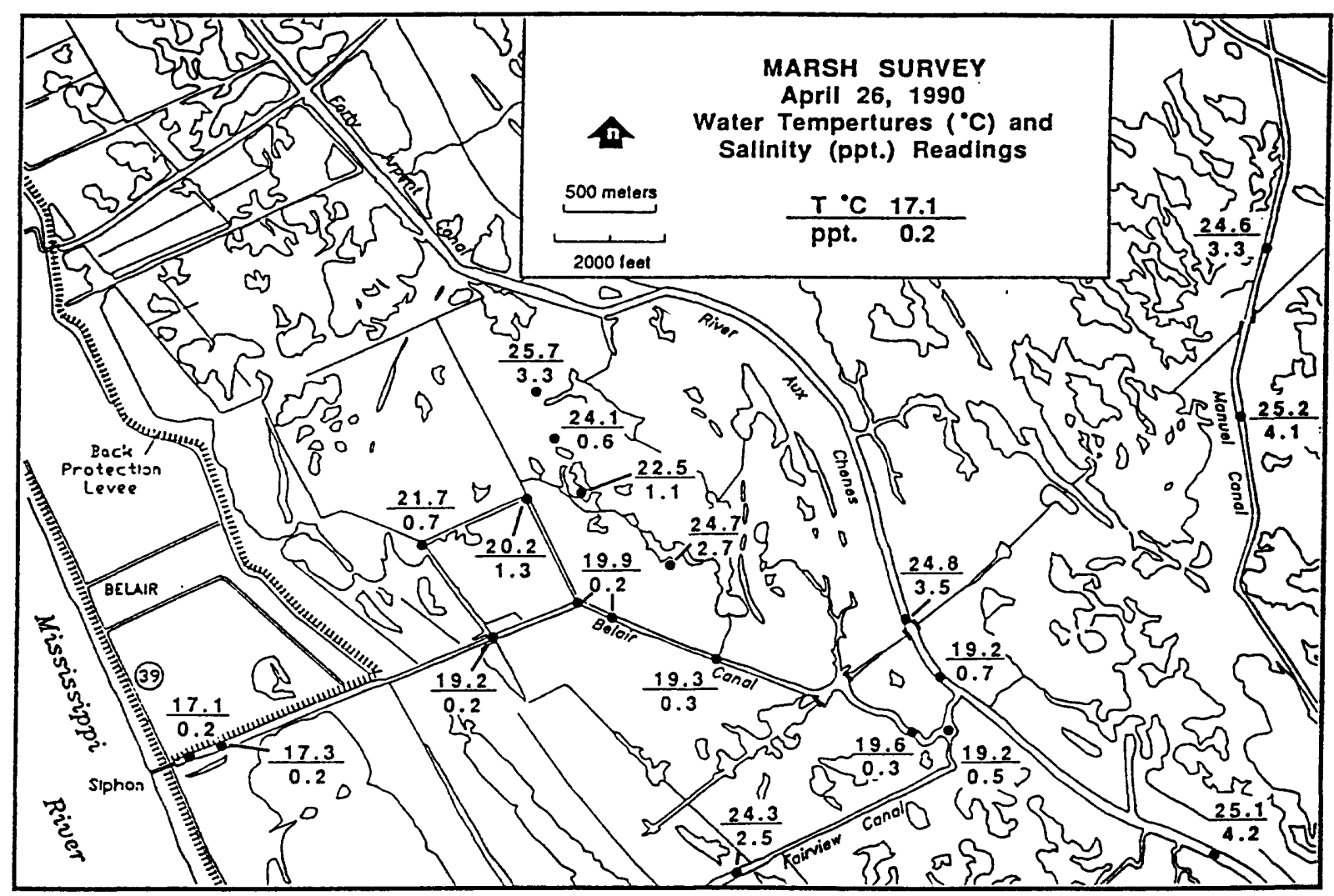

Figure 3-10. The distribution of water temperatures and salinity in water bodies during the marsh survey. 


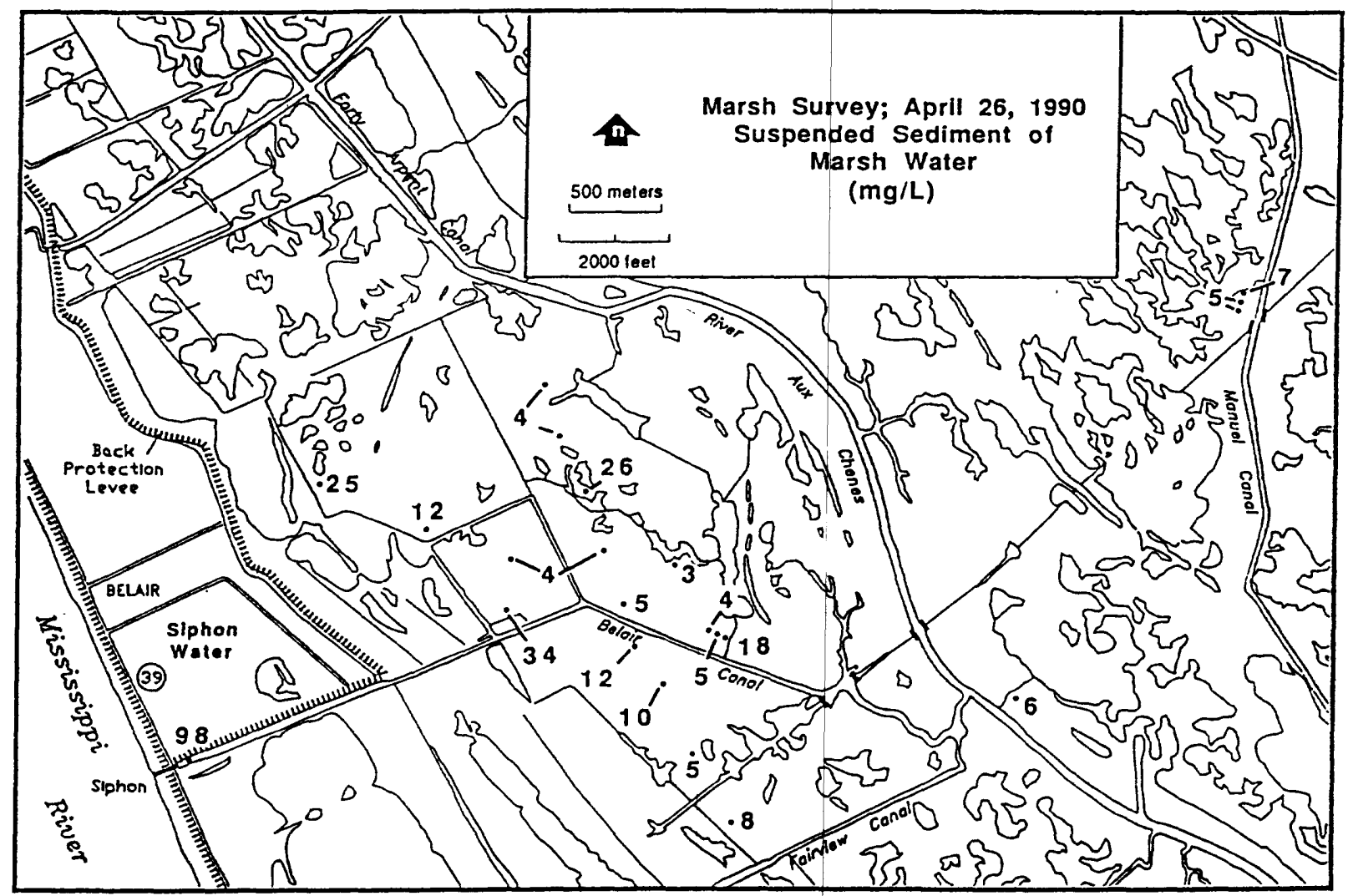

Figure 3-11. Distribution of suspended sediment concentrations in marsh water during the survey. 


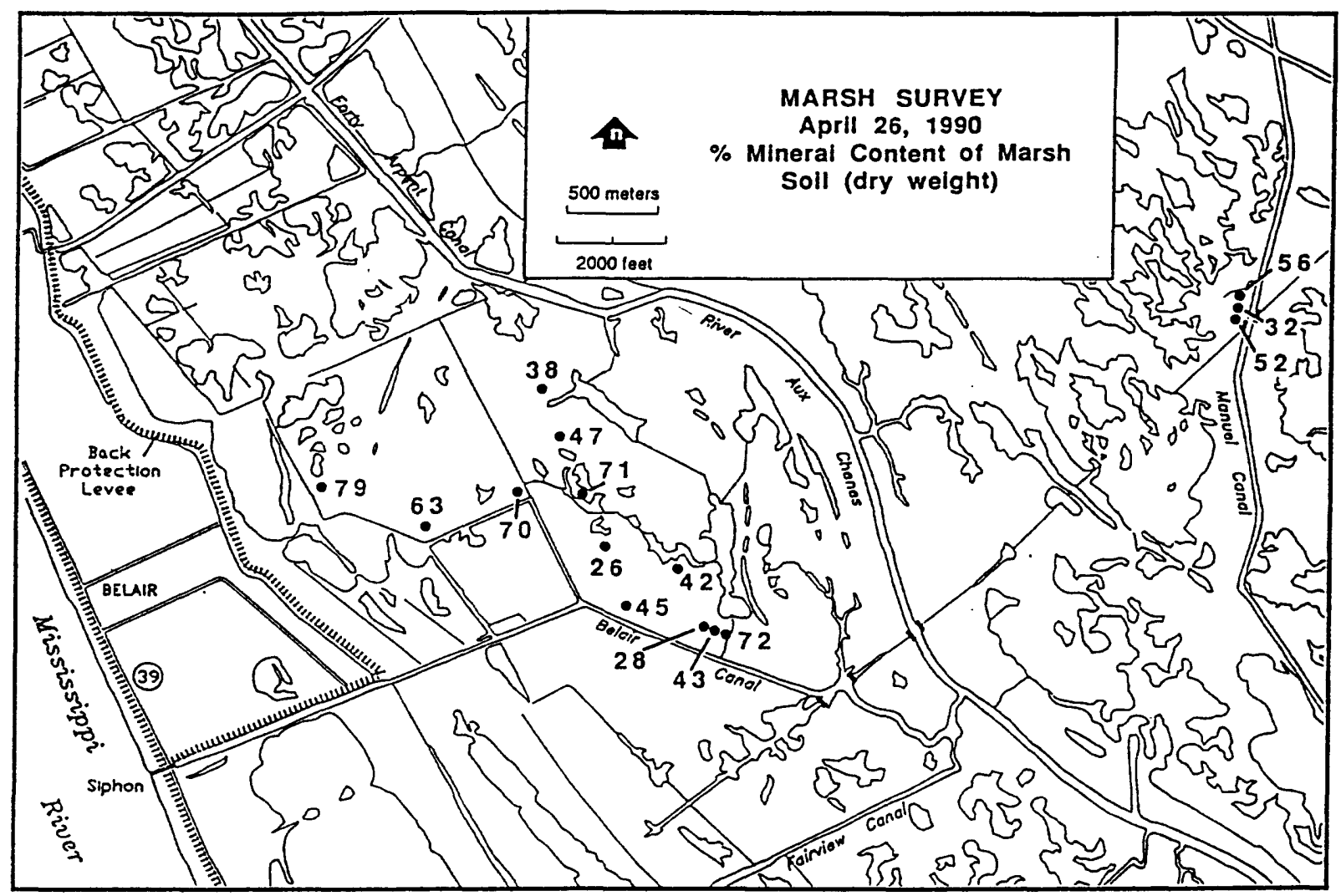

Figure 3-12. Distribution of mineral content (percent dry weight) in marsh soils sampled during the marsh survey. 
Replicate intact soil samples show differences in the soil characteristics of ME and MC with distance from the streambank (Table 3-2). The differences, where noted, are significant at the 5 percent probability level; otherwise, the values are stated as similar. Comparison of means with distance from the streambank within-site indicate that water content is slightly less and mineral content slightly greater at $1 \mathrm{~m}$ than at 30 and $100 \mathrm{~m}$ at MC (Figure 3-13). The MC organic content at $1 \mathrm{~m}$ and $100 \mathrm{~m}$ is similar, but is slightly lower at $30 \mathrm{~m}$. At $\mathrm{ME}$, water content is substantially less and mineral content much greater at $1 \mathrm{~m}$ than at 30 and $100 \mathrm{~m}$. The relative organic content is similar for all three locations (Figure 3-13).

Table 3-2. Physical Characteristics of Marsh Soils from Experimental and Control Sites as a Function of Distance from the Water's Edge.

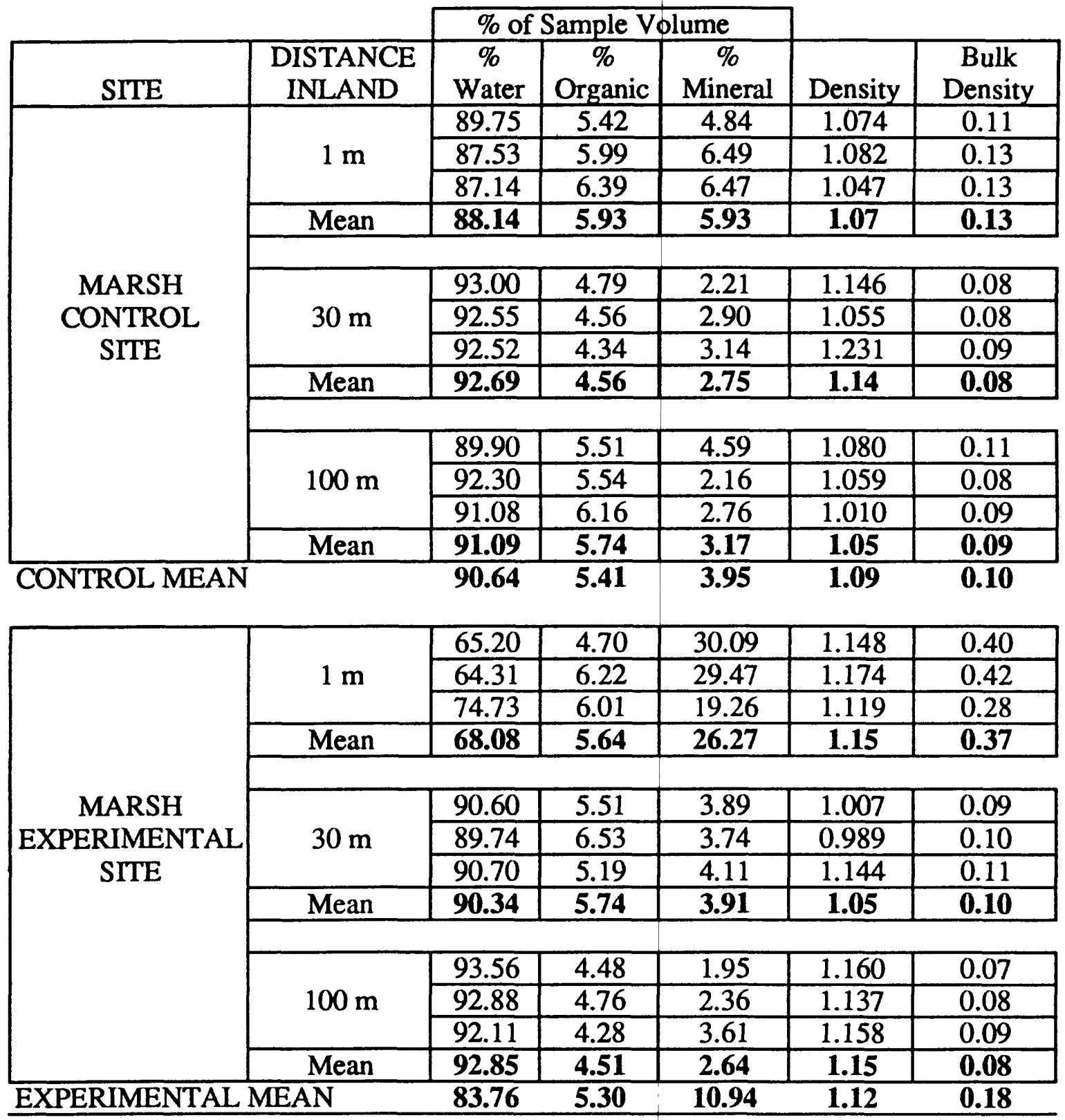

Note: Density units are $\mathrm{g} / \mathrm{cm}^{2}$. 


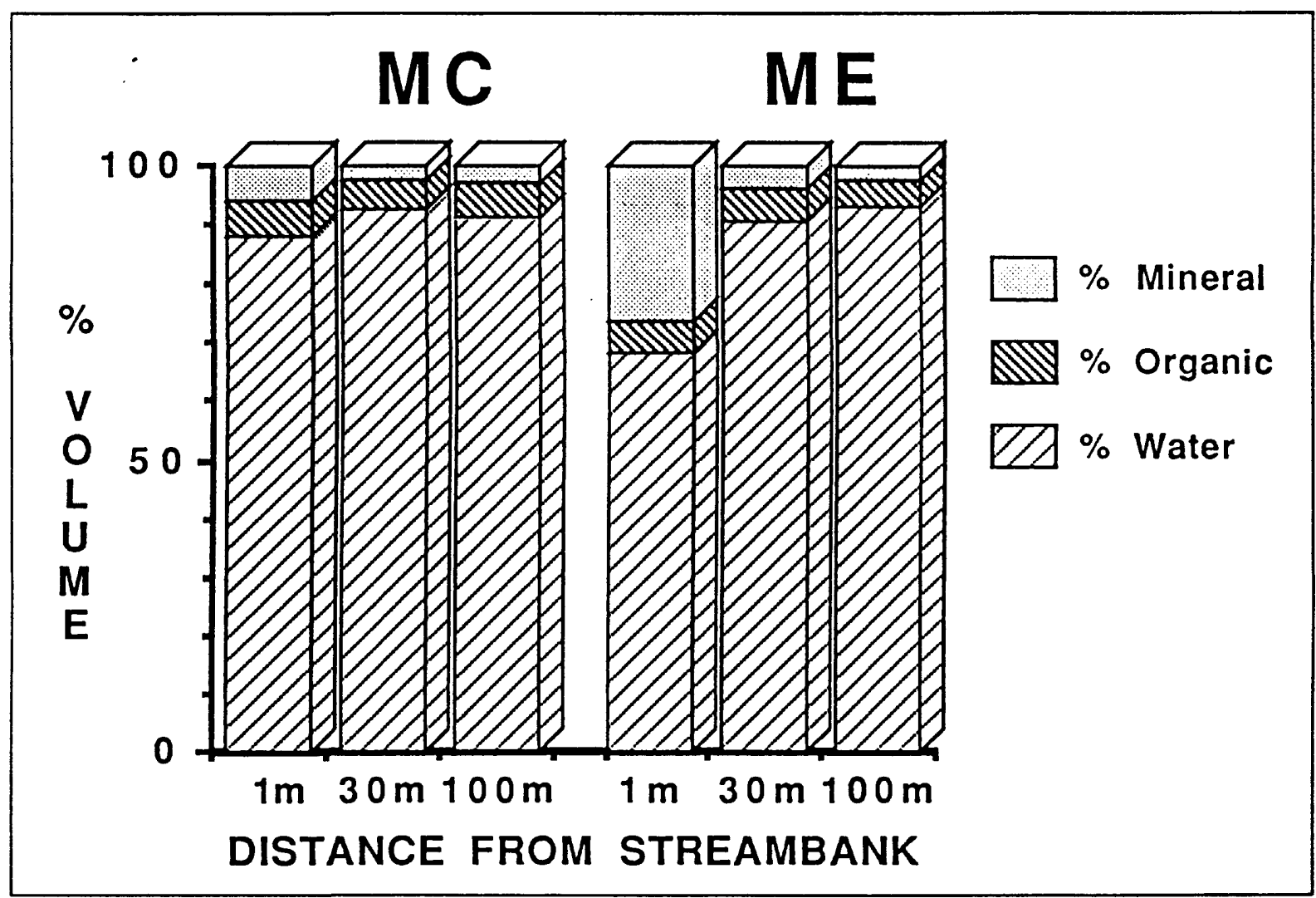

Figure 3-13. The water, organic, and mineral volume of marsh soil at marsh experimental (ME) and control (MC) sites.

Differences between sites at the same distance also exist. At $1 \mathrm{~m}$ from the streambank, water content is much greater and mineral content much less at MC in comparison with $\mathrm{ME}$; organic content is similar at both. At $30 \mathrm{~m}$, water content is only slightly greater at MC, and the organic and mineral content is slightly greater at ME. At $100 \mathrm{~m}$, the water and mineral content are similar at MC and ME, and a slightly greater organic content exists at MC.

Both sites exhibit a streambank effect, with mineral content decreasing inland from the stream; however, the effect is more pronounced at ME, presumably because of sediment input from the siphon. Overall, the organic content is fairly constant, ranging from 4.3 to 6.5 percent across all samples. Water and mineral volume are inversely related. High-mineral, low-water content soils are relatively firm, as is the case for ME at the 1-m location. Low-mineral, high water-content soils are very spongy and quakey, as found at the 30 and $100 \mathrm{~m}$ stations at both sites (Table 3-2).

The above results are generally in agreement with earlier findings. According to Nyman and others (1990), brackish marsh has an average composition of 90.86 percent water and gas, 5.11 percent organic matter, and 4.03 percent mineral matter. This composition matches closely with the control site measurements, which average 90.64 percent water and gas, 5.41 percent organic matter, and 3.95 percent mineral matter and with the measurements at the $30-$ and $100-\mathrm{m}$ experimental sites which average 87.05 percent water and gas, 5.13 percent organic matter, and 3.28 percent mineral matter. The experimental streamside site at $1 \mathrm{~m}$ with 26.27 percent mineral matter is well in 
excess of the highest values recorded by Nyman and others (1990), which was 6.89 percent mineral for saline marsh.

The accretion from January 11 to July 20 measured over feldspar marker horizons at $\mathrm{ME}$ and $\mathrm{MC}$ is shown in Figure 3-14. At $1 \mathrm{~m}$, the $14 \mathrm{~mm}$ accretion at ME greatly exceeds that of $5.2 \mathrm{~mm}$ at $\mathrm{MC}$ and all other sites. Also at $\mathrm{ME}$, there is an orderly reduction of accretion from $8.5 \mathrm{~mm}$ to $3.8 \mathrm{~mm}$ with distance from the streambank. Mineral sediment input from the siphon is a logical explanation. At MC, the accretion of 5.2 and $7.5 \mathrm{~mm}$ at $1 \mathrm{~m}$ and $30 \mathrm{~m}$, respectively, are not significantly different. At $100 \mathrm{~m}$, the characteristics of the soil did not produce a definable horizon (Figure 3-14). Because of the spongy, porous consistency of the surface, the feldspar material was diffused throughout a several-centimeter-thick zone in the soil, making accretion measurements impossible. The large disparity between the streamside ME accretion and the other sites may also be partially due to seasonal factors. The cycle sampled includes the times of maximum mineral sediment availability from the siphon, but the time of maximum organic input occurs later in the year after the growing season. The additional element of the marsh burning added to the disparity by removing almost all standing dead material.

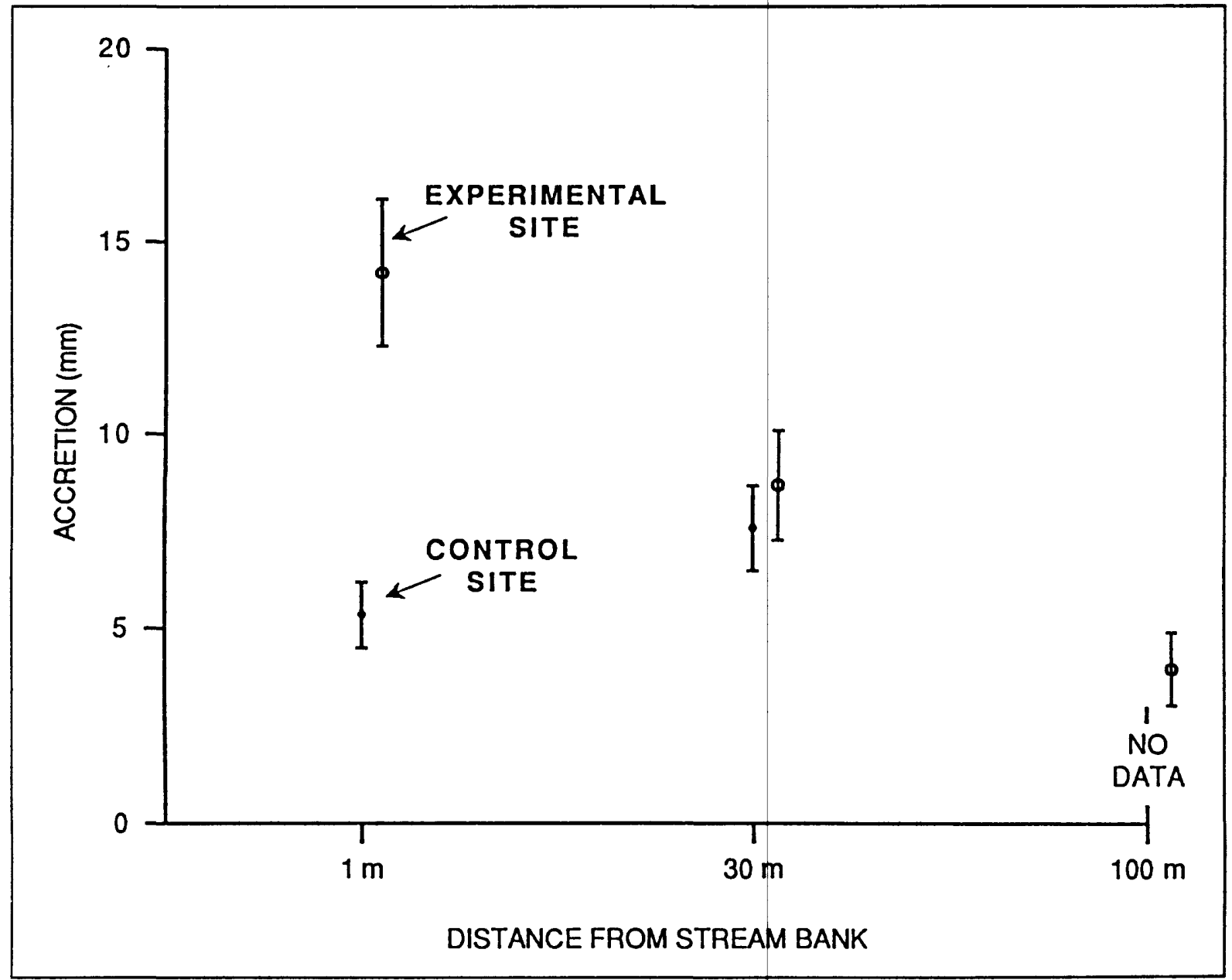

Figure 3-14. Sediment accretion as a function of distance from the stream bank at the marsh experimental and control sites after 162 days. 
The study of mineral and organic sediment accumulation using ceramic sediment traps showed wide variability within the depositional environments over the period of study. The results of analyses of variance on two treatments at three distances from the streambanks over three time intervals is shown in Appendix B. Few statistically significant findings were evident using the mean and variance from four observations in each test. The wide variability within each depositional environment, as seen in the field, is due to the variability in the marsh surface elevation which controls the hydroperiod, and hence, the rate of deposition (Table 3-3). Also, biological influences were important, as discussed below. To reduce the effects of this on the data, the weights of the four observations (a $361 \mathrm{~cm}^{2}$ area) were combined for presentation.

\begin{aligned} \hline Table 3-3. Variability of the Marsh \\ Surface at Marsh Study Sites. \end{aligned}

\begin{tabular}{|c|c|c|}
\hline STATIONS & ME & MC \\
\hline Relative & 0.38 & 0.00 \\
\cline { 2 - 3 } & 0.57 & 0.17 \\
\cline { 2 - 3 } Marsh & 0.17 & 0.06 \\
\cline { 2 - 3 } Surface & 0.26 & 0.20 \\
\cline { 2 - 3 } & 0.30 & 0.28 \\
\cline { 2 - 3 } Readings & 0.00 & 0.24 \\
\cline { 2 - 3 } & 0.39 & 0.10 \\
\cline { 2 - 3 } (feet) & 0.27 & 0.12 \\
\cline { 2 - 3 } & 0.36 & 0.31 \\
\cline { 2 - 3 } & 0.42 & 0.21 \\
\hline RANGE (ft) & 0.57 & 0.31 \\
\hline VARIANCE & 0.024 & 0.010 \\
\hline STD. DEV. & 0.154 & 0.099 \\
\hline STD. ERROR & 0.049 & 0.031 \\
\hline
\end{tabular}

Figure 3-15 shows the total dry weights of mineral and organic sediments trapped at 94, 159, and 226 days at stations ME and MC. At station ME, the first 94-day period ending on April 16 shows the effects of the early high sediment concentrations in the diverted water. The pattern of mineral input confirms again the strong streambank effect. Organic sedimentation does not vary greatly over the entire 226-day period at ME. As discussed above, the initial burning of the marsh removed standing dead material which would not be formed again until the end of the growing season. Between 94 and 159 days, the mineral sediment accumulation did not increase, but is shown to have slightly decreased. Water levels dropped below marsh level only 4 days during this 65 day period (Figure 3-5), and suspended sediment concentrations were in the range of 90 $\mathrm{mg} / \mathrm{L}$ (Appendix A). Between 159 and 226 days, the mineral sediment accumulation increased, surpassing the 94-day values. Water levels rose above and fell below marsh level 6 times over periods of 2 to 4 days each. The suspended sediment concentration was still in the range of $90 \mathrm{mg} / \mathrm{L}$, and the siphon was not in operation during 20 days of this 67-day period. Logically, the conditions from 94 and 159 days should have introduced more mineral sediments than from 159 to 226 days. It is suggested that emptying and filling of the marsh introduces more sediment than water levels rising and falling above a marsh floor that is already flooded. 


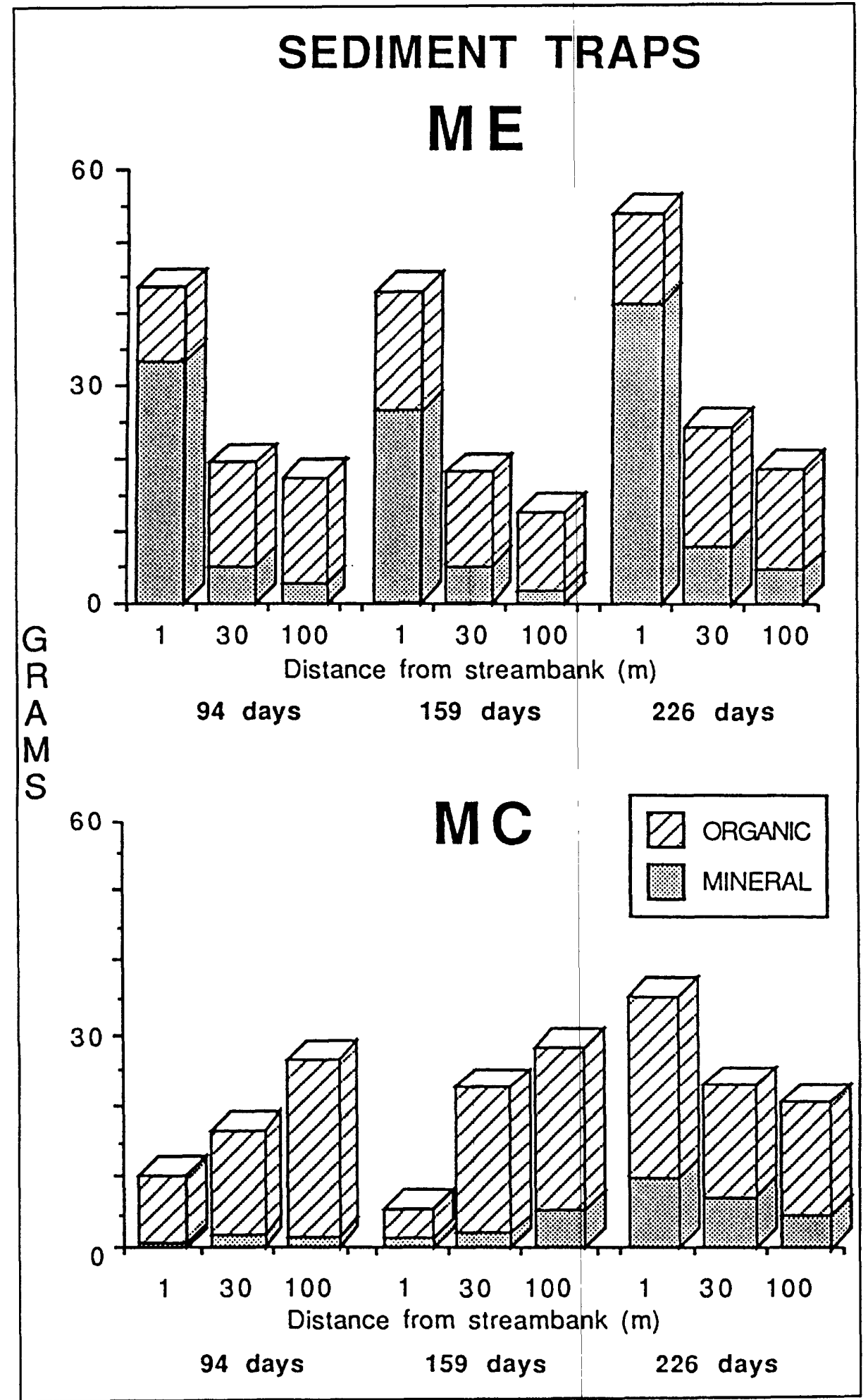

Figure 3-15. Results of the sediment-trapping study at the marsh experimental (ME) and control (MC) sites. 
At MC, the mineral input is much less than at ME (Figure 3-15). The marsh burning at MC, compared to that at ME, was not as complete in terms of removal of standing dead plant material. The thatch was not as thick and continuous at MC, resulting in a less intense fire and more organic accumulation. The 94- and 159-day samples showed a reverse streamside effect, and the 226-day samples show a major episode of accumulation at the 1-m station. Field observations indicated that the depositional environments at MC experienced significant biological influences during the study period. The stands of three-cornered grass at the site attracted nutria (Myocastor coypus), which grub the marsh floor in search of plant roots. In the process of digging, soil material was thrown onto some traps and some were partially undermined. Some of the vertical extensions of some traps were broken, and one trap contained a nutria fecal pellet. This biological activity resulted in more accumulation than would have otherwise occurred.

The experiment illustrated some of the effects that mammals have on sedimentation rates in two different marsh areas. At MC, the effects were detrimental. Feeding activity removed a renewable portion of the marsh volume (the roots) and created avenues of water exchange, formerly described as micro-drainage features. With limited sediment availability for introduction, these drainage features may result in net removal of material from the marsh. The effects at ME are similar, but the resulting micro-drainage features allow suspended sediment from the siphon discharge to travel farther into the marshes where it is most needed.

\section{Implications for Wetland Conservation and Management}

For the 1990 diversion season, the White's Ditch Siphon added 70.3 million $\mathrm{m}^{3}(57,000$ ac-ft) of freshwater to the Breton Sound Basin. The average basin discharge from P-PE amounts to approximately $58.06 \mathrm{cms}(2,050 \mathrm{cfs})$ (van Beek and others, 1984) or 1.851 billion $\mathrm{m}^{3} / \mathrm{yr}$ ( 1.5 million ac-ft/yr). The siphon amounts to a 3.8 percent increase in average P-PE. Additionally, the siphon introduced approximately 12 million $\mathrm{kg}$ of riverine sediment. To estimate the acreage of marsh that can be maintained by this quantity of mineral sediment, recent studies by Nyman and others (1990) and Penland and Ramsey (1990) can be used, assuming total retention of the sediment and equal distribution over the outfall area. Nyman and others (1990) estimate the mineral matter required to maintain brackish marsh in $\mathrm{g} / \mathrm{m}^{2} / \mathrm{yr}$ as $1052 \mathrm{x}$ (rate of submergence). By substituting a submergence rate of $1.1 \mathrm{~cm} / \mathrm{yr}$ (Penland and Ramsey, 1990), the siphon can maintain a maximum of $1,037.61 \mathrm{ha}(2,562 \mathrm{ac})$. As the field studies have shown, conditions in the outfall area do not allow 100 percent retention nor an even distribution of diverted sediment; sediment benefits occurred only in the first $30 \mathrm{~m}$ of the streambank.

Sediment transport into the marsh is a necessity if sediment benefits are to be derived from freshwater diversions. The results of the siphon outfall investigation suggest that such benefits will depend greatly on the environmental setting and may be limited in the upper estuary where tidal and wind-induced water velocities are at a minimum and the "basin effect" is pronounced. Because a major portion of the sediment benefit involves silts, the benefit will be partially limited to the immediate stream banks only, unless open water areas are available for infilling and conversion to emergent wetlands.

Lower in the basin along the bay margins, hydrologic energy is much greater, increasing the potential for mobilization and transport of clays and silts into marsh areas. Mossa and Roberts (1990) describe the coincidental occurrence of maximum riverine 
sediment supply and the peak mobilization of nearshore Gulf and bay sediments caused by cold fronts. Pre-frontal conditions resuspend sediments that move into the bays and coastal marshes during elevated water levels, and post-frontal conditions move sediment out into the bays and nearshore Gulf. Even under these higher energy conditions, shorelines and streambanks are favored in terms of net mineral input and show higher accretion rates than areas just inland.

The higher rate of mineral sediment deposition along stream banks, even to the exclusion of interior marsh, is important in wetland management in general and management of freshwater diversion projects in particular. The establishment of laminar, overbank sheetflow of water over the marshes is often believed to be a requirement for marsh maintenance. This may be true with regard to input of freshwater, nutrients, and dissolved minerals in cases where organic material accumulation is most important, primarily the fresh and intermediate marshes (Nyman and others, 1990). However, distribution of mineral sediments to inland marshes cannot be achieved through overbank sheetflow. Outfall management of freshwater diversion structures is necessary for distribution of mineral sediments. One aspect of this management should be design of secondary, tertiary, and micro-drainage conduits that provide the optimum drainage density for the area of influence, particularly with regard to siphons.

The "basin effect" described earlier in this chapter can be identified as a constraint with regard to distribution of mineral sediment in the outfall area. The effect produces some quantity of residual ambient water that acts against the introduction of sediment-laden water into the marsh. When the ambient water level is less than marsh level, inflow during a rise in stage can introduce water (and sediment) farther into the area. Data from the sediment-trapping experiment gives support to this statement. One method of overcoming the basin effect is to establish unidirectional flow from the outfall source through the outfall area through the use of watercontrol structures (van Beek and others, 1986; Mossa and Roberts, 1990).

Wetland management techniques, such as water-control structures, should optimize inflow during pre-frontal stages to allow sediment introduction. In like manner, the same control structures should seek to retain the sediments during post-frontal conditions. This is an important concept in outfall management of freshwater diversions. For example, flap-gate type water-control structures in conjunction with properly designed drainage features could greatly enhance sediment introduction from the White's Ditch Siphon. During pre-frontal conditions, elevated water levels in the Belair Canal would open the gates and allow flow into the marsh. During post-frontal conditions the gates would prevent backflow into the Belair Canal, forcing the diverted water to exit at distant sites in the planned drainage system. 


\section{CHAPTER 4 SUMMARY AND CONCLUSIONS}

The long-term maintenance and renewal of the wetland resource base of the Mississippi River Deltaic Plain cannot be accomplished without diversion of sediment-laden water from the Mississippi and Atchafalaya Rivers. Sediments are needed to replace lost wetlands and to help offset the accretion deficit in most of the remaining wetlands. To date, however, diversions have focused primarily on providing freshwater for the purpose of salinity control, and sediment introduction associated with these diversions has received little attention. This study evaluated to what extent freshwater diversions can contribute to wetland maintenance from a sediment suppletion perspective. The potential sediment contribution from freshwater diversions was determined by examining the discharge and sediment load characteristics of the Mississippi River and the constraints posed on the operation of diversion structures by fisheries resources. Additionally, a field study evaluated the potential of siphons as a wetland maintenance and restoration measure. Siphons are a tested method for small-scale water transfer from the Mississippi River to adjacent estuaries and are more readily implemented by local and state government because of the smaller cost and fewer constraints than those of diversion structures (such as those implemented at Caernarvon and proposed for Davis Pond). Two such siphons are operational, and two are presently being implemented.

\section{Freshwater Diversion}

The primary goal of current freshwater diversions is to optimize productivity of fish and wildlife resources by controlling salinity through introduction of freshwater in the upper part of the estuary. While the operation for wildlife resources is constrained only by water levels, fisheries resources require management of water introduction with regard to salinity and temperature. The primary constraint is oyster production, because of its economic value; oyster production can be directly related to freshwater inflow and salinity management. Therefore, a target annual salinity regime has been established to guide operation of the recently completed Caernarvon and future diversion structures. In most years, the target regime would not require full use of the diversion capacity during the period when the potential for sediment diversion is greatest.

The highest diversion potential for freshwater is determined by river stage. Stages are generally high from January though early May and, on the average, peak in mid-April. But because of drainage basin characteristics, maximum sediment availability occurs in March, with high sediment concentrations extending generally from December through April. Clay concentrations show a relatively minor change with discharge. Silt concentrations increase gradually with discharge to a peak in March. Sand concentrations along the lower Mississippi River appear to increase rapidly after the discharge exceeds 400,000 cfs and generally are highest during the April flood flows.

The most important shellfish and finfish populations allow freshwater diversion to be maximized for wetland maintenance purposes without adverse effects from December through March. A subsequent reduction of diversion in April would allow timely reestablishment of target salinities and would reduce adverse siltation and maintenance cost related to deposition of sands and coarse silts in the freshwater distribution systems 
of the outfall area. By maximizing diversion discharges during the period of December through March when a reduction of salinities in the estuary does not appear to be critical, a 24 percent increase in sediment introduction can be achieved.

\section{Field Study - White's Ditch}

To further evaluate the potential contribution of freshwater diversions to wetland maintenance, in particular diversions through siphons, a field study was undertaken at the White's Ditch Siphon, in Plaquemines Parish. This siphon, with a flow capacity of $220 \mathrm{cfs}$, transfers water from the Mississippi River into a hydrologic subbasin of the Breton Sound estuary. Measurements were made to evaluate delivery and distribution of freshwater and sediment and to determine the effect of the siphon discharge on marsh maintenance. The field program compared conditions within the siphon outfall area with those in an adjacent sub-basin beyond the influence of the diverted water but in an otherwise similar hydrologic setting. Because of siphon operation, the field observations focused on the period of January through June.

Delivery of materials by the siphon was evaluated using discharge determinations for water and suspended sediment and core-samples of bottom sediments. Discharges were governed primarily by river stage and secondarily by climatic events such as frontal passages. Changes in wind direction associated with frontal passage caused water levels in the upper estuary to change by as much as $30 \mathrm{~cm}$ ( $1 \mathrm{ft}$ ). The effect of astronomical tide on siphon discharges was minimal. During the period of January 11, 1990, through July 27,1990 , the siphon added 70.3 million $\mathrm{m}^{3}(57,000 \mathrm{ac}-\mathrm{ft})$ of freshwater and 12 million $\mathrm{kg}$ (13,200 tons) of sediment to the Breton Sound estuary. The freshwater suppletion represents an increase of approximately 20 percent of the freshwater normally available from precipitation surplus in the subbasin within which the siphon discharges.

Sediment concentrations were found to range from $230 \mathrm{mg} / \mathrm{L}$ in February to $102 \mathrm{mg} / \mathrm{L}$ in June; total sediment delivery ranged from $1092 \mathrm{~g} / \mathrm{s}$ to $640 \mathrm{~g} / \mathrm{s}$ for the same months. However, only a portion of this sediment contributes to wetland maintenance in the vicinity of the siphon. The main loss of sediment resulted from deposition in the outfall canal. As much as 20 percent of the sediment, nearly all sand and silt, may be lost to deposition before water and suspended sediments are dispersed into adjacent wetlands. A second loss, probably to water bodies of the lower estuary, involved silts and clays that bypassed the wetlands adjacent to the outfall channel. As much as 27 percent of the sediment was found to bypass the wetlands even during a rising tide. This occurred where adjacent wetlands were semi-confined by natural or man-made features, limiting through-flow and reducing the response of water levels to normal tidal fluctuations. The wetland basins filled with water during periods of persistent or substantial increase in water levels to elevations that exceeded subsequent high water levels in the outfall canal for some time.

Freshwater and sediment dispersions into the wetlands were greatest during southerly and easterly wind events. This condition of maximum input was monitored through aerial reconnaissance, measurements of water temperature, and sampling of marsh water and marsh soils. For a suspended sediment concentration at the siphon outfall of $100 \mathrm{mg} / \mathrm{L}$, highest concentrations in the marsh were found to be $30 \mathrm{mg} / \mathrm{L}$, or about 60 percent less than those of the siphon water, and were associated with micro-drainage features. Away from such drainage features, values dropped commonly to $5-10 \mathrm{mg} / \mathrm{L}$. 
The effect of the diversion on wetland accretion was evaluated by means of soil sampling, feldspar horizons, and sediment-trapping devices at locations extending from a tidal channel bank, across which sediments were being delivered to the interior marsh. These observations involved both the siphon area and an area removed from siphon influence and occurred at distances of $1 \mathrm{~m}, 30 \mathrm{~m}$, and $100 \mathrm{~m}$ from the channel bank. The measurable effect of the siphon diversion on soil composition appeared limited to a narrow zone along channel banks. Soil sampling showed mineral content of the soils to be highest along the stream bank at both field sites, with differences between interior marsh and the stream bank most pronounced at the site receiving siphon water. Mineral content of the marsh soil did not differ significantly between the two sites for locations equal or greater than $30 \mathrm{~m}$ from the stream bank. Changes occurred mostly in the proportion of water/mineral volume, the organic content remaining fairly constant and at about 5 percent. Mineral matter accounted generally for about 3 to 4 percent, except at the stream bank in the siphon area where it reached 26 percent.

Accretion measurements showed a pattern similar to the soil characteristics. Accretion on feldspar marker horizons over the period from January to July did not differ significantly between the two sites for locations equal or greater than $30 \mathrm{~m}$ from the stream bank. It amounted to about $5 \mathrm{~mm}$ at all sites except for the channel bank in the siphon area. Accretion at the latter location was $14 \mathrm{~mm}$. No channel bank effect was apparent in the control area.

Accretion on ceramic sediment-trapping devices showed greater variability, but again confirmed the higher mineral sediment component at the stream banks, particularly in the siphon area. Organic sedimentation did not vary greatly in the siphon area and showed random variation in the control area. The sediment trap data suggested that flooding and dewatering of the marsh provides for greater sediment introduction than does water-level variation of a continuously flooded marsh.

Freshwater diversions constitute a major source of sediments for wetland maintenance when considering the quantity of sediments introduced. For the Caernarvon Diversion, it was estimated that nearly 500,000 tons of sediment would be introduced during a year of average river stages and average local rainfall conditions (van Beek and others, 1984). The present study suggests that volume of sediments could be readily increased by at least 100,000 tons without adversely affecting commercial fisheries harvests. The significance of this becomes apparent when one considers that this supplemental quantity of sediments represents the accretion deficit of some 8,500 ha $(21,000 \mathrm{ac})$ under typical subsidence rates.

The siphon field study, on the other hand, indicates that much of the benefit from sediments diverted as an inherent component of freshwater diversions can be realized only if sediments are adequately dispersed through the marsh. Without measures for outfall management, sediment deposition will be confined mostly to the outfall channel and the banks of the major distribution channels, and an excessive part of the sediments may be shunted through the wetlands depending on physical setting. To achieve greater dispersion of sediment in the wetlands, it is necessary to either provide for a high density distribution network of "trainasse" type channels, coupled with measures that enhance throughflow of water, or divert water at rates and under conditions that allow overflow of the marsh to a depth and at velocities sufficient to carry a portion of the suspended clay particles well into the marsh. The latter would mimic historic, natural conditions of overbank flow of the Mississippi River and its distributaries and is more likely to be 
achieved when water levels in the estuary are elevated as a result of periodic climatic events such as frontal passage.

The greatest sediment benefit from both siphons and large-scale freshwater diversions will be obtained when deposition of coarse-grained sediments in the immediate vicinity of the discharge point creates emergent wetlands. Accordingly, from a wetland restoration and maintenance perspective, the optimal location for freshwater diversions is in the upper estuaries into shallow water bodies with subsequent dispersion of water and fine-grained sediments into surrounding marshes. Without the selection of proper locations, management of the outfall, and timing of diversion discharges relative to river conditions and estuarine water levels, sediment benefits frem freshwater diversions may remain limited. With those attributes, freshwater diversions, including siphons, can be an effective tool in the maintenance of the wetland resource base of the Mississippi River Deltaic Plain. 


\section{REFERENCES}

Barrett, B.B., and M. Gillespie, 1973, Primary factors which influence commercial shrimp production in coastal Louisiana: Louisiana Department of Wildlife and Fisheries Technical Bulletin 9.

Breithaupt, R.L., and R.J. Dugas, 1979, A study of the southern oyster drill (Thaishae mastoma) distribution and density on the oyster seed grounds: Louisiana Department of Wildlife and Fisheries Technical Bulletin 30.

Chatry, M., R.J. Dugas, and K.A. Easley, 1983, Optimum salinity regime for oyster production on Louisiana's State seed grounds: Contributions in Marine Science 26, p. 81-94.

Chatry, M., and M.J. Millard, 1986, Effects of 1983 floodwaters on oysters in Lake Borgne, the Louisiana Marsh, Western Mississippi Sound, and Chandeleur Sound: Louisiana Department of Wildlife and Fisheries Technical Bulletin 40, p. 1-13.

Chatry, M., 1990, Personal communication from field observations near Palmetto Bayou, Barataria Basin.

Dugas, R.J., 1977, Oyster distribution and density on the productive portion of the State seed grounds in southeastern Louisiana: Louisiana Department of Wildlife and Fisheries Technical Bulletin 23.

Dugas, R.J., and W.S. Perret, 1976, The effects of 1973 spring floodwaters on oyster populations in Louisiana: Proceedings of the Southeastern Association of Game and Fish Commissioners 29, p. 208-214.

Everett, D.E., 1971, Hydrologic and quality characteristics of the lower Mississippi River: Louisiana Department of Public Works and U.S. Geological Survey, Baton Rouge, Technical Report 5, $48 \mathrm{p}$.

Folk, R.L., 1968, Petrology of sedimentary rocks: Hemphill Publishing Company, Austin, Texas, $175 \mathrm{p}$.

Galtsoff, P.S., 1964, The American oyster, Crassostrea virginica Gmelin: U.S. Fish and Wildlife Service Fishery Bulletin 64.

Herke, W.H., and B.D. Rogers, 1988, Threats to coastal fisheries, in Marsh Management in Coastal Louisiana: Effects and Issues: U.S. Department of the Interior, Fish and Wildlife Service, Biological Report 89(22), p. 196-212.

Lindall, W., J. Hall, J. Sykes, and E. Arnold, Jr., 1972, Louisiana coastal zone: analyses of resource and resource development needs in connection with estuarine ecology, in Fishery Resources and Their Needs: Prepared for the U.S. Army Corps of Engineers, New Orleans District. (Contract No. 14-17-002-430) National Marine Fisheries Service, Biological Laboratory, St. Petersburg Beach, Florida, Sections 10 and 13.

Louisiana Department of Wildlife and Fisheries (LDWF), variour years, Unpublished data from the public oyster seed grounds in Breton Sound.

Mossa, J., 1988, Discharge-sediment dynamics of the lower Mississippi River: Transactions of the Gulf Coast Association of Geological Societies 38, p. 303-314. 
Mossa, J., and H.H. Roberts, 1990, Synergism of riverine and winter storm-related sediment transport processes in Louisiana's coastal wetlands: Transactions of the Gulf Coast Association of Geological Societies 40, p. 635-642.

Nyman, J.S., R.D. Delaune, and W.H. Patrick, Jr., 1990, Wetland soil formation in the rapidly subsiding Mississippi River Deltaic Plain: mineral and organic relationships: Estuarine, Coastal, and Shelf Science 31, p. 57-69.

Owen, H.M., 1955, The oyster industry of Louisiana: Louisiana Wildlife and Fisheries Commission, Division of Oysters, Water Bottoms, and Seafoods, New Orleans, unpublished manuscript, $387 \mathrm{p}$.

Penland, S., and K.E. Ramsey., 1990, Relative sea-level rise in Louisiana and the Gulf of Mexico: Journal of Coastal Research 6, p. 323-342.

Schechter, V., 1943, Tolerance of the snail (Thais floridana) to waters of low salinity and the effect of size: Ecology 24(4), p. 493-499.

Smith, D.A., 1979, Documentation of the use of a brackish-water estuarine zone as a nursery ground by Penaeid shrimp: Master's Thesis, Louisiana State University, Baton Rouge, $91 \mathrm{p}$.

Tabony, M., 1972, A study of the distribution of oyster larvae and spat in southeastern Louisiana: Master's Thesis, Louisiana State University, Baton Rouge, $70 \mathrm{p}$.

Tocho, J., 1988, Personal communication regarding construction of the White's Ditch Siphon: Engineer, Prescott, Follette, and Associates, New Orleans, Louisiana.

U.S. Army Corps of Engineers (USACE), 1984, Louisiana coastal area, Louisiana-freshwater diversion to Barataria and Breton Sound basins: New Orleans District.

, 1986, Louisiana coastal areas study - interim report on freshwater diversion to Barataria and Breton Sound basins: New Orleans District.

, 1990, Unpublished data for the Mississippi River at Tarbert Landing: New Orleans District, Gaging Section, New Orleans, Louisiana.

various years, Stages and discharges of the Mississippi River and Tributaries in the New Orleans District: New Orleans, Louisiana.

van Beek, J.L., D.Roberts, and T.Duenckel, 1984, A management plan for freshwater diversion at Caernarvon, Louisiana: Coastal Environments, Inc., Baton Rouge, Louisiana, $90 \mathrm{p}$.

van Beek, J.L., T.J. Duenckel, P.C. Howard, K.J., Meyer-Arendt, D.W. Roberts, and S.M. Gagliano, 1986, Long-term management and protection of Plaquemines Parish: Prepared by Coastal Environments, Inc., Baton Rouge, Louisiana, for Plaquemines Parish Commission Council, 263 p. 


\section{APPENDICES}


Appendix A. Discharge (Q), suspended sediments (TSS), and suspended load calculations for the White's siphon from 1990 field measurements.

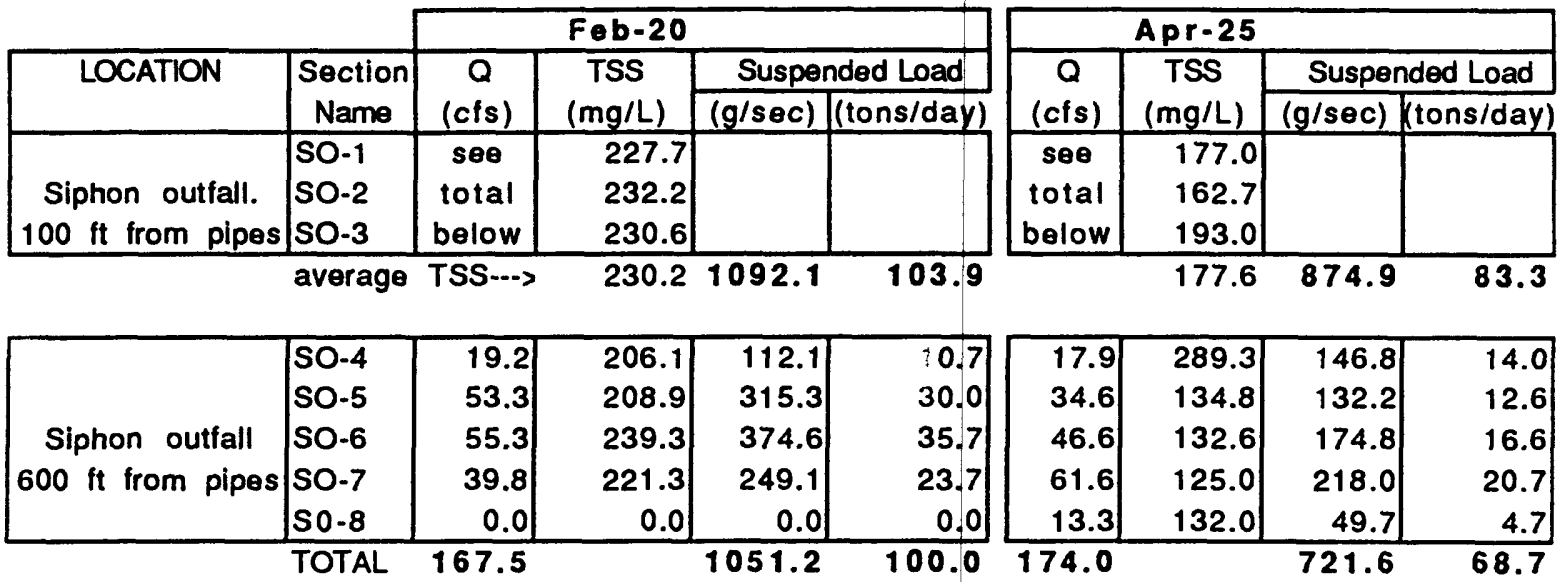

\begin{tabular}{|c|c|c|c|c|c|c|c|c|c|}
\hline JUNCTION & $\begin{array}{l}\mathrm{J} 1 \\
\mathrm{~J} 2\end{array}$ & -22.7 & 191.2 & -122.8 & -11.7 & $\begin{array}{l}-17.0 \\
-25.7 \\
\end{array}$ & $\begin{array}{l}100.0 \\
100.0\end{array}$ & $\begin{array}{r}-48.2 \\
-72.9 \\
\end{array}$ & $\begin{array}{l}-4.6 \\
-6.9 \\
\end{array}$ \\
\hline & TO1 & .22 .7 & & -122.8 & .11 .7 & -42.8 & & 121.1 & .11 .5 \\
\hline
\end{tabular}

\begin{tabular}{c|c|c|r|r|r|r|r|r|r|r|}
\hline & BC1-a & & 142.7 & 0.0 & 0.0 & 6.5 & 73.8 & 13.6 & 1.3 \\
Bolair Canal & BC1-b & 26.5 & 245.6 & 184.4 & 17.5 & 34.4 & 82.5 & 80.4 & 7.7 \\
(BC1) & BC1-C & 65.3 & 147.9 & 273.6 & 26.0 & 55.4 & 76.3 & 119.6 & 11.4 \\
& BC1-d & 10.2 & 174.6 & 50.4 & 4.8 & 32.4 & 115.0 & 105.5 & 10.0 \\
& BC1-o & & 144.1 & 0.0 & 0.0 & 8.8 & 111.7 & 27.7 & 2.6 \\
\hline
\end{tabular}

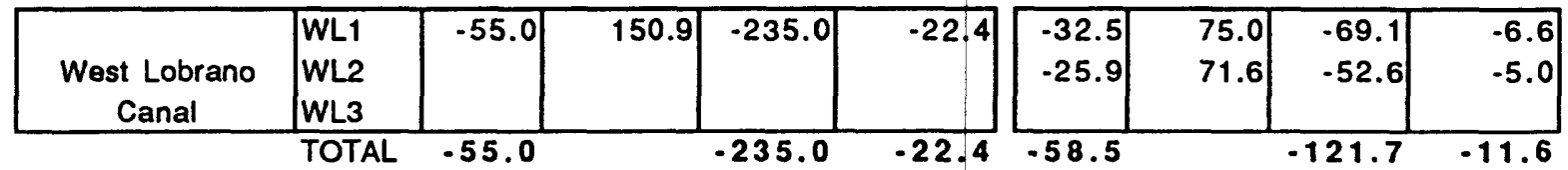

\begin{tabular}{|c|c|c|c|c|c|c|c|c|c|}
\hline $\begin{array}{c}\text { East Lobrano } \\
\text { Canal }\end{array}$ & $\begin{array}{l}\text { EL1 } \\
\text { EL2 }\end{array}$ & -63.5 & 149.6 & -269.0 & -25.6 & $\begin{array}{l}-44.1 \\
-42.6 \\
\end{array}$ & $\begin{array}{l}30.1 \\
63.2 \\
\end{array}$ & $\begin{array}{r}-37.6 \\
-76.3 \\
\end{array}$ & $\begin{array}{l}-3.6 \\
-7.3 \\
\end{array}$ \\
\hline & TOTAL & .63 .5 & & -269.0 & .25 .6 & -86.7 & & -113.9 & -10.8 \\
\hline $\begin{array}{l}\text { Bolair Canal } \\
\text { (BC2) }\end{array}$ & $\begin{array}{l}B C 2-a \\
B C 2-b \\
B C 2-c \\
B C 2-d\end{array}$ & -16.5 & 112.4 & -52.5 & -5.0 & $\begin{array}{l}3.0 \\
3.6 \\
2.5\end{array}$ & $\begin{array}{r}47.4 \\
40.8 \\
108.5\end{array}$ & $\begin{array}{l}4.1 \\
4.1 \\
7.7\end{array}$ & $\begin{array}{l}0.4 \\
0.4 \\
0.7\end{array}$ \\
\hline
\end{tabular}

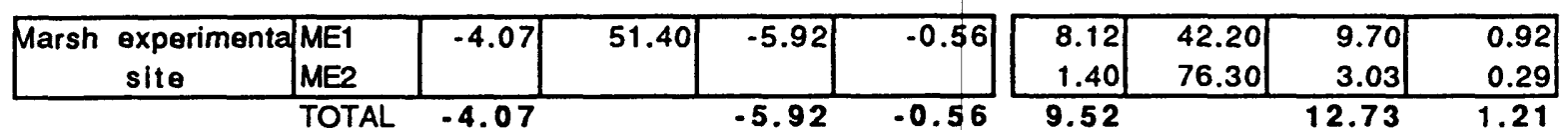

\begin{tabular}{rl|l|l|l|l|l|l|l|l|r|}
\hline $\begin{array}{c}\text { Marsh control } \\
\text { site }\end{array}$ & $\begin{array}{l}\text { MC1 } \\
\text { MC2 }\end{array}$ & 2.75 & 14.80 & 1.15 & 0.11 \\
\hline TOTAL & 2.75 & & & 1.28 & 14.50 & 0.53 & 0.05 \\
0.75 & 31.40 & 0.67 & 0.06 \\
\hline
\end{tabular}


Appendix A. Continued

\begin{tabular}{|c|c|c|c|c|c|}
\cline { 3 - 6 } \multicolumn{2}{c|}{} & \multicolumn{4}{c|}{ May-25 } \\
\hline LOCATION & Section & $Q$ & TSS & \multicolumn{2}{|c|}{ Suspended Load } \\
\cline { 5 - 6 } & Name & (cfs) & (mg/L) & (g/sec) & (tons/day) \\
& $S O-1$ & see & 148.7 & & \\
Siphon outfall. & SO-2 & total & 188.7 & & \\
$100 \mathrm{ft}$ from pipes & SO-3 & below & 214.3 & & \\
\hline
\end{tabular}
$\begin{array}{lllll}\text { average TSS--.> } & 183.9 & 952.9 & 90.7\end{array}$

\begin{tabular}{|c|r|r|r|}
\hline \multicolumn{3}{|c|}{ Jun-20 } \\
\hline $\mathrm{Q}$ & $\mathrm{TSS}$ & \multicolumn{2}{|c|}{ Suspended Load } \\
\cline { 3 - 4 } (cfs) & (mg/L) & (g/sec) & (tons/day) \\
\hline se日 & 113.6 & & \\
total & 97.7 & & \\
below & 94.6 & & \\
\hline
\end{tabular}

\begin{tabular}{|l|r|r|r|r|}
\hline SO-4 & 16.1 & 111.9 & 51.1 & 4.9 \\
SO-5 & 53.7 & 142.4 & 216.4 & 20.6 \\
SO-6 & 47.3 & 146.4 & 196.1 & 18.7 \\
SO-7 & 59.4 & 136.3 & 229.2 & 21.8 \\
SO-8 & 6.5 & 111.4 & 20.6 & 2.0 \\
\hline TOTAL & 183.0 & & 713.3 & 67.9
\end{tabular}

\begin{tabular}{|r|r|r|r|}
\hline 32.3 & 103.5 & 94.7 & 9.0 \\
152.4 & 109.7 & 473.5 & 45.1 \\
37.1 & 104.7 & 109.9 & 10.5 \\
& & & \\
\hline 221.8 & & & \\
\hline
\end{tabular}

\begin{tabular}{|l|l|l|l|l|l|}
\hline JUNCTION & $\begin{array}{l}\text { J1 } \\
\text { J2 }\end{array}$ & -14.9 & 109.8 & -46.4 & -4.4 \\
\hline
\end{tabular}

\begin{tabular}{|c|c|c|c|}
\hline-7.5 & 84.7 & -18.0 & -1.7 \\
\hline-1.2 & 93.8 & -3.1 & -0.3 \\
\hline
\end{tabular}

\begin{tabular}{c|l|r|r|r|r|}
\hline & BC1-a & 24.7 & 96.1 & 67.2 & 6.4 \\
Belair Canal & BC1-b & 64.5 & 94.9 & 173.2 & 16.5 \\
(BC1) & BC1-C & 39.8 & 92.7 & 104.4 & 9.9 \\
& BC1-d & & & & \\
\hline & BC1-e & & & & \\
\hline \multicolumn{3}{r}{ TOTAL 128.9}
\end{tabular}

\begin{tabular}{|r|r|r|r|}
\hline 77.7 & 95.4 & 209.9 & 20.0 \\
114.3 & 95.5 & 309.2 & 29.4 \\
18.9 & 83.3 & 44.6 & 4.2 \\
& & & \\
\hline 210.9 & & & \\
\hline
\end{tabular}

\begin{tabular}{r|l|r|r|r|r|r|r|r|r|}
\hline \multirow{2}{*}{$\begin{array}{c}\text { West Lobrano } \\
\text { Canal }\end{array}$} & WL1 & -9.4 & 88.6 & -23.7 & -2.3 & -5.4 & 95.1 & -14.6 & -1.4 \\
& WL2 & -12.8 & 98.3 & -35.7 & -3.4 & -19.2 & 77.9 & -42.3 & -4.0 \\
WL3 & & & & & -15.5 & 84.0 & -36.9 & -3.5 \\
\hline
\end{tabular}

\begin{tabular}{|c|c|c|c|c|c|c|c|c|c|}
\hline $\begin{array}{c}\text { East Lobrano } \\
\text { Canal }\end{array}$ & $\begin{array}{l}\text { EL1 } \\
\text { EL2 } \\
\end{array}$ & \begin{tabular}{r|}
-1.4 \\
0.0 \\
\end{tabular} & $\begin{array}{l}57.9 \\
58.1 \\
\end{array}$ & \begin{tabular}{r|}
-2.3 \\
0.0 \\
\end{tabular} & \begin{tabular}{r|}
-0.2 \\
0.0 \\
\end{tabular} & \begin{tabular}{r|}
-12.5 \\
-3.5 \\
\end{tabular} & $\begin{array}{l}83.8 \\
89.9 \\
\end{array}$ & $\begin{array}{r}-29.6 \\
-8.8 \\
\end{array}$ & $\begin{array}{l}-2.8 \\
-0.8 \\
\end{array}$ \\
\hline & TOTAL & -1.4 & & -2.3 & -0.2 & -15.9 & & .38 .4 & -3.7 \\
\hline $\begin{array}{l}\text { Belair Canal } \\
\text { (BC2) }\end{array}$ & $\begin{array}{l}B C 2-a \\
B C 2-b \\
B C 2-C \\
B C 2-d\end{array}$ & \begin{tabular}{l|}
29.0 \\
56.7 \\
15.8
\end{tabular} & $\begin{array}{l}87.9 \\
93.7 \\
86.3\end{array}$ & $\begin{array}{r}72.3 \\
150.4 \\
38.6\end{array}$ & $\begin{array}{r}6.9 \\
14.3 \\
3.7\end{array}$ & $\begin{array}{r}3.4 \\
93.2 \\
76.5 \\
3.3\end{array}$ & $\begin{array}{l}80.1 \\
89.2 \\
89.9 \\
91.7\end{array}$ & $\begin{array}{r}7.6 \\
235.5 \\
194.8 \\
8.5\end{array}$ & $\begin{array}{r}0.7 \\
22.4 \\
18.5 \\
0.8\end{array}$ \\
\hline
\end{tabular}

\begin{tabular}{|c|c|c|c|c|c|c|c|c|c|}
\hline $\begin{array}{c}\text { Marsh experimenta } \\
\text { site }\end{array}$ & ME1 & 4.56 & 66.90 & 8.64 & 0.82 & 1.41 & 73.20 & 2.92 & 0.28 \\
\hline & ME2 & 4.06 & 71.80 & 8.26 & 0.79 & 1.56 & 59.70 & 2.64 & 0.25 \\
\hline
\end{tabular}

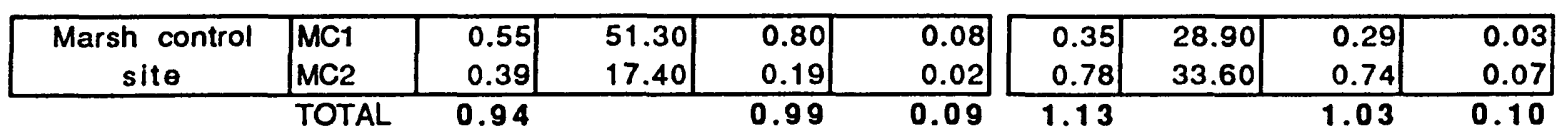


Appendix B. The results of an analysis of variance (ANOVA) on sediment trap data. The experimental design includes 12 traps at each of three distances from streambanks at experimental and control sites ( 72 traps). The traps were retrieved in sets of 24 at three time intervals.

\begin{tabular}{|c|c|c|c|c|c|c|c|}
\hline \multirow{2}{*}{\multicolumn{2}{|c|}{ INFLUENCE OF TIME }} & \multicolumn{3}{|c|}{ Experimental } & \multicolumn{3}{|c|}{ Control } \\
\hline & & $1 \mathrm{~m}$ & $30 \mathrm{~m}$ & $100 \mathrm{~m}$ & $1 \mathrm{~m}$ & $30 \mathrm{~m}$ & $100 \mathrm{~m}$ \\
\hline \multirow[t]{2}{*}{94 vs 159 days } & Mineral & 1.83 & -0.05 & 0.28 & -2.88 & -0.10 & -0.96 \\
\hline & & -1.60 & 0.50 & 0.96 & -2.75 & -1.38 & 0.63 \\
\hline \multirow[t]{2}{*}{159 vs 226 days } & & -3.78 & -0.6 & $-0.73^{*}$ & 0.53 & -1.25 & 0.13 \\
\hline & & 05 & & -0.75 & -1.23 & 1.15 & 1.75 \\
\hline \multirow[t]{2}{*}{94 vs 226 days } & & -1.95 & & -0.45 & $-2.35^{\circ}$ & -1.35 & $-.085^{*}$ \\
\hline & Organic & -0.55 & -0.55 & 0.23 & $-3.97^{\prime}$ & -0.225 & 2.38 \\
\hline
\end{tabular}

\section{INFLUENCE OF DISTANCE}

\begin{tabular}{|c|c|}
\hline $1 \mathrm{~m}$ vs $30 \mathrm{~m}$ & Mineral \\
\cline { 2 - 2 } & Organic \\
\hline $30 \mathrm{~m}$ vs $100 \mathrm{~m}$ & Mineral \\
\cline { 2 - 2 } & Organic \\
\hline $1 \mathrm{~m}$ vs $100 \mathrm{~m}$ & Mineral \\
\cline { 2 - 2 } & Organic \\
\hline
\end{tabular}

\section{Experimental} \begin{tabular}{|c|c|c|c|c|c|}
\hline 94 days & 159 days & 226 days & 94 days & 159 days & 226 days \\
\hline 7.18 & $4.44^{\circ}$ & &
\end{tabular} $7.18^{*}$

$-1.10$
$4.24^{\circ}$ 1.00 0.63 $-0.10$ $7.80^{*}$ $-1.20$

0.95

0.38

$6.25^{*}$
1.38 8.48 $-1.10$ 0.83 0.68

9.30 $-0.43$

\begin{tabular}{|c|c|c|}
\hline-0.40 & $2.38^{*}$ & 0.60 \\
\hline-1.08 & 0.23 & $2.60^{*}$ \\
\hline-0.08 & -0.80 & 0.56 \\
\hline-2.63 & -0.63 & -0.03 \\
\hline-0.33 & 1.58 & 1.18 \\
\hline-3.70 & -0.40 & $2.58^{*}$ \\
\hline
\end{tabular}

\section{INFLUENCE OF TREATMENT}

\begin{tabular}{|c|c|c|c|c|}
\hline \multirow{2}{*}{$1 \mathrm{~m}$} & Mineral & 84 days & 159 days & 226 days \\
\cline { 2 - 5 } & Organic & 0.10 & -1.65 & -7.95 \\
\hline \multirow{2}{*}{$30 \mathrm{~m}$} & Mineral & 0.78 & 0.73 & $3.33^{*}$ \\
\cline { 2 - 5 } & Organic & 0.05 & -1.83 & -0.08 \\
\hline \multirow{2}{*}{$100 \mathrm{~m}$} & Mineral & 0.23 & $-1.03^{*}$ & 0.18 \\
\cline { 2 - 5 } & Organic & -2.48 & -2.83 & 0.33 \\
\hline
\end{tabular}

Values are mean difference ( $A$ vs $B=A-B$ ) Number of observations per calulation of variance is 4 .

- Denotes significance at $95 \%(p<0.05)$. 